Florida International University FIU Digital Commons

11-19-1999

\title{
The role of Mercosur in the post cold war security context of the southern cone of the Americas
}

\author{
Alex Easdale \\ Florida International University
}

DOI: $10.25148 /$ etd.FI15101260

Follow this and additional works at: https://digitalcommons.fiu.edu/etd

Part of the Latin American Studies Commons

\section{Recommended Citation}

Easdale, Alex, "The role of Mercosur in the post cold war security context of the southern cone of the Americas" (1999). FIU Electronic Theses and Dissertations. 3111.

https://digitalcommons.fiu.edu/etd/3111 


\section{FLORIDA INTERNATIONAL UNIVERSITY}

Miami, Florida

\section{THE ROLE OF MERCOSUR IN THE POST COLD WAR SECURITY CONTEXT OF THE SOUTHERN CONE OF THE AMERICAS}

A thesis submitted in partial fulfillment of the

requirements for the degree of

MASTER OF ARTS

in

LATIN AMERICAN STUDIES

by

Alex Easdale

1999 
To: Dean Arthur W. Herriott

College of Arts and Sciences

This thesis, written by Alex Easdale, and entitled The Role of MERCOSUR in the Post Cold War Security Context of the Southern Cone of the Americas, having been approved in respect to style and intellectual content, is referred to you for judgment.

We have read this thesis and recommend that it be approved.

Douglas Kincaid

Luis G. Solís

Eduardo Gamarra, Major Professor

Date of Defense: November 19, 1999

The thesis of Alex Easdale is approved.

Dean Arthur W. Herriott College of Arts and Sciences

Dean Richard L. Campbell Division of Graduate Studies

Florida International University, 1999 
(C) Copyright 1999 by Alex Easdale

All rights reserved. 


\section{ACKNOWLEDGMENTS}

I wish to thank the members of my thesis committee for their support, feedback, and patience. Dr. Douglas Kincaid introduced a sociological perspective that was enlightening. His and Dr. Eduardo Gamarra's work on the militarization of police functions was very useful for my purposes. Luis G. Solís offered excellent analysis in relation to the relevance of historical relations in the Southern Cone, as well as helpful comments regarding models of regional integration. His opinions were very thought provoking and constructive. The ideas and thoughts of my major professor, Eduardo Gamarra, provided the impetus for my interest in this project. He was flexible in allowing me to elaborate and develop certain concepts, while reminding me of the importance of a central theme that runs throughout the thesis. His firmness, availability and persistence are truly appreciated. Indeed, he has been a true mentor.

I wish to express my most sincere appreciation to the following Argentine functionaries. Counselor Marcelo Cima's ministerial thesis on present Argentine civilmilitary relations was very helpful. Our numerous discussions on themes relevant to this project were refreshing and encouraging. Minister Eduardo Mallea put into perspective the MERCOSUR stance with respect to the FTAA negotiations. His expertise on legal matters was critical to my elaboration of the present Argentine-Paraguayan impasse on the Oviedo extradition issue. Counselor Elena Mikusinski de Rossi appealed to the importance involved in strategic relations between Argentina and Brazil, and has often times argued for the need to re-launch the MERCOSUR project in light of recent 
setbacks. Ambassador Alfredo Morelli put MERCOSUR into clear economic perspective. His comments were honest and his stance offered an interesting contrast to the main postulates of this work.

I also wish to thank my following colleagues for their comments and assistance. Mike Collier's paper on the Paraguayan democratic transition greatly contributed to the third chapter of this thesis. His arguments were convincing and telling, and I owe much of the structure of that chapter to him. Paul Vicary and Pablo Toral provided valuable insight for the theoretical framework of my thesis. I want to thank Amy Dickinson for her invaluable patience and support throughout this endeavor. Finally, I wish to thank my family for their support, understanding and guidance. 


\author{
ABSTRACT OF THE THESIS \\ THE ROLE OF MERCOSUR IN THE POST COLD WAR SECURITY \\ CONTEXT OF THE SOUTHERN CONE OF THE AMERICAS \\ by \\ Alex Easdale \\ Florida International University, 1999 \\ Miami, Florida \\ Professor Eduardo Gamarra, Major Professor
}

The purpose of this study is to determine whether the Southern Common Market (MERCOSUR) plays a role in facilitating multilateral security mechanisms among its members. The central question of this work asks whether regional integration results in the establishment of cooperative security mechanisms.

The dependent variable involves multilateral security initiatives within the MERCOSUR, in the present context of inter-American relations. The independent variables include regional transitions to democracy, the regional strategic consequences of the ending of the Cold War, and regional integration experiments. This work departs from the stated central question to the particular case of international involvement in the Paraguayan political crises of 1996 and 1999. The active intervention of Paraguay's 
largest MERCOSUR partners, Brazil and Argentina, in the course of these developments is analyzed.

The evidence demonstrates that economic integration does not necessarily result in the establishment of formal cooperative security mechanisms. In the present context of inter-American relations, however, there exists a tendency toward multilateral regional responses to internal threats to democracy as witnessed in the Paraguayan case. This project shows that membership in a regional economic organization, as seen by the ASEAN, European Union and MERCOSUR, enhances the establishment of common security measures. 


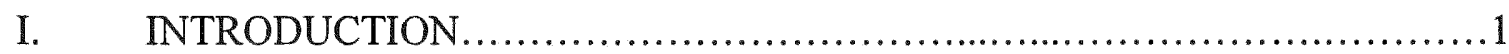

Chapter Breakdown.......................................................

Theoretical Framework.......................................................5

Integration................................................................. 5

Security and Regionalism................................................ 9

The Cases of Western Europe and The Asia-Pacific Region......................14

The European Union and Security............................................14

The Case of Asian-Pacific Cooperation.......................................20

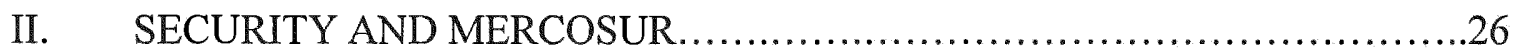

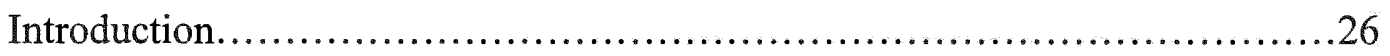

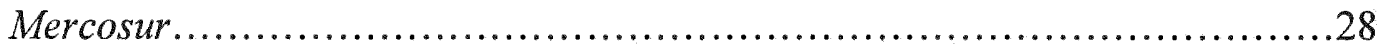

Institutional Characteristics of Mercosur.........................................30

The New Security Context of the Western Hemisphere .............................35

Cooperative Security .........................................................37

Security Implications of Integration in the Southern Cone......................41

In Search of a New Role for the Military .....................................44

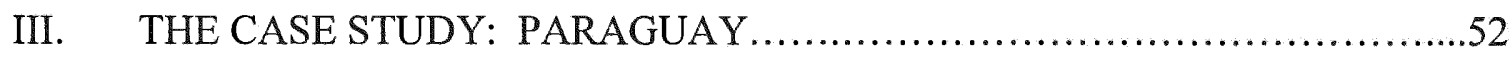

The Paraguayan Transition To Democracy ....................................54

The Stroessner Legacy......................................................55

The Rodríguez Regime and the Rise of Lino Oviedo..........................59

The 1996 Coup and Mercosur.................................................64

The Oviedo-Wasmosy Nexus............................................64

International Reaction to the Coup.......................................68

The Short-Lived Cubas Presidency ........................................71

Regional Diplomacy in Response to Internal Crises..........................75

The Detriment of Paraguayan Relations with Argentina and Uruguay...........80

IV. TRENDS AND CONCLUSIONS........................................... 86

Post Cold War Security in the Southern Cone..................................87

Conclusion...........................................................93

LIST OF REFERENCES.................................................. 103 


\section{CHAPTER 1}

\section{INTRODUCTION}

Ultimately, the significance and place of regionalism in post Cold War security will be determined by its effectiveness in promoting the security of participating states. ${ }^{1}$

On April 22, 1996 Paraguayan General Lino Oviedo gathered his troops some twelve kilometers south of Asunción and declared himself in rebellion against the President of the Republic, Juan Carlos Wasmosy, in an attempt to overthrow him. This extreme action was rooted in a decree signed by Wasmosy that called for the forced retirement of Oviedo, who also served as head of the armed forces of that country. ${ }^{2}$ The immediate reaction against the coup attempt by Paraguay's Southern Common Market (MERCOSUR) partners was unprecedented. The governments of Argentina, Brazil and Uruguay gave their full support to Wasmosy and made it clear that democracy is a fundamental condition for membership into the Southern Common Market (MERCOSUR). Several other key players in the international community, such as the Organization of American States (OAS) and the United States, also played an important part during the institutional crisis. Of particular interest to this thesis is that Paraguay's largest MERCOSUR trade partners intervened in this country's domestic political situation to help preserve democratic governance. These occurrences may bring to light curious parallels in the economic and security realms with respect to integration. Evidence that will be later presented points to a pattern in which states may be utilizing

${ }^{1}$ Muthiah Alagappa, 1995, pp. 156-157. 
international economic organizations to further their and their neighbors' security interests. Therefore, the central question of this project is whether, in the post-Cold War context of international relations, regional economic integration will lead to the eventual establishment of cooperative security mechanisms in the Southern Cone.

A fundamental assumption of this thesis is that in the post-Cold War era, the rapid process of globalization has been the force behind the regional economic integration experiments in Europe, Asia and Latin America. By globalization I refer to a phenomenon that may be identified in the pronounced increase in production processes and financial transaction flows across national borders, which are organized on a transnational basis. $^{3}$ Furthermore, globalization contains no necessary notion of enhancing inter-state cooperation, and may indeed expose several limitations in the structures of international economic governance. States are as a result faced with declining autonomy over their economic policy agenda and seek to regain control. This, in turn, may help explain declining support for multilateral experiments, and the increased interest in bilateral and regional accords, which have accompanied globalization. ${ }^{4}$ States, then, seek to integrate at the (sub) regional level. Taken a step further, I will contend that in the post Cold War era, economic integration experiments in Europe, Asia and Latin America may give rise to new forms of cooperative security. To fully explain the relationship between new forms of security and economic experiments,

\footnotetext{
${ }^{2}$ La Nación newspaper, Menem se solidarizó con Wasmosy, April 23, 1996.

${ }^{3}$ Francisco Rojas Aravena, 1998: 13. See also Gautam Sen, 1999: 61-2. Sen argues that globalization reflects to closer integration of the world economy as measured by trade/GNP ratios and international flows of FDI (Foreign Direct Investment) and financial capital than does internationalization. He adds that in contrast to national exports and imports of goods and services, the organization, flow and purview of FDI and global capital, undertaken by transnational corporations, assume a global marketplace.

${ }^{4}$ Notes from International Political Economy seminar, Professor Copeland. The theoretical framework established in the first chapter discusses and defines, for the purposes of this work, regional integration.
} 
this thesis will examine the case of MERCOSUR, and particularly its role in the internal security of Paraguay during two serious recent institutional crises: the 1996 Oviedo coup attempt, and the 1999 [vice-president] Argaña assassination.

\section{CHAPTER BREAKDOWN}

This introductory chapter will first attempt to explain the broad relationship between the nature of economic integration and cooperative security arrangements in the post-Cold War era. Through a review of relevant literature, I will examine the relationship between economic regionalism and cooperative security. As a point of departure, the first chapter will provide a theoretical framework with relevant concepts that are deemed important to understand the impact that the end of the Cold War and other international processes are having at the state and regional level. The third section will analyze whether the end of the Cold War has resulted in cooperative security mechanisms in certain prominent economic regions, namely the European Union and the APEC/ASEAN region.

The second chapter will put recent political and economic developments of the Western Hemisphere into context. First, a brief overview of MERCOSUR will be provided, and its institutional characteristics will be analyzed (given that formal dispute settlement mechanisms are key to the success of any economic integration scheme). Second, the post Cold War content of strategic-security issues in the Western Hemisphere will be explored. Finally, this chapter will analyze the security implications of politicaleconomic integration in the Southern Cone. In doing so, current trends in the present 
context of civil-military relations will be analyzed, as will proposals for collective defense in MERCOSUR.

The case study method will be utilized in the third chapter. Keeping in mind the central question, recent political developments in Paraguay and their subsequent repercussions will be discussed since they brought in other international actors. The major events that merit attention are the March 1996 coup attempt by General Lino Oviedo, and the institutional political crises that erupted with the March 1999 assassination of then Vice-President Luis Maria Argaña. The ongoing dilemma involving unsuccessful Paraguayan attempts to extradite Oviedo, who has attained political asylum in Argentina, is key given that this issue continues to hamper relations between these two countries. A discussion of the so-called government-military-Colorado Party tripartite ruling structure that was established during Alfredo Stroessner's dictatorship is deemed necessary since it could be argued that Paraguayan politics have not necessarily moved away from it. ${ }^{5}$ This is key to an analysis of the Paraguayan democratic process since institutional crises in this country have resulted in the direct involvement of its main MERCOSUR trading partners.

The concluding chapter of this project will discuss relevant trends presently occurring in the Southern Cone. Certain setbacks in the relations between the MERCOSUR countries will be analyzed, as the possibilities that this organization has for success. I will also explore potential repercussions for democracy and regionalism that certain trends, such as the militarization and privatization of police functions, may have

\footnotetext{
${ }^{5}$ Mike Collier, 1998: 3. This citation comes from Collier's paper: Civil-Military Relations in Paraguay: Business as Usual, which was written as a course requirement for Eduardo Gamarra's South American Politics (CPO 6936) class.
} 
on these countries furthering their attempts at integration. Hence, the still undefined role to be played by the region's militaries (in light of the conceptual broadening of the definition of security) becomes a relevant issue regarding integration attempts by these countries since generals with political ambitions such as Oviedo threaten processes to deepen regional integration within a context of democracy. Thus, and in light of this research, I will explain what the Paraguayan case tells us about MERCOSUR's role in the establishment of cooperative security mechanisms among its members.

\section{THEORETICAL FRAMEWORK}

\section{INTEGRATION}

The most striking impact of globalization on the state is precisely the integration of internal and external functions, and, associated with that, the increasing interaction between security policy and economic policy, both of which now have an important internal and external dimension. ${ }^{6}$

In economic, environmental, political, and even military issues, governments increasingly feel obliged to act together, thereby giving rise to an intricate pattern of cooperation and competition. As a result, several constraints on a state's freedom of action arise. ${ }^{7}$ As a result of the increasing difficulties governments face in trying to act alone, there is a greater the need for policy coordination. Furthermore, and in this context, international institutions place additional limitations on the practical options available to sovereign states. "The net effect is a network of contacts, coalitions, and interactions within and between national societies that escape the control of the central policy organs of

\footnotetext{
${ }^{6}$ Edward L. Morse, 1970: 371-392.
} 
government." ${ }^{\prime 8}$ Put simply, the scope of central governmental institutions has narrowed while societies are becoming increasingly interdependent.

It could be argued that interdependence exists and operates in a variety of ways, among a range of participants in a political system, whether at the sub-national, national, or international level. ${ }^{9}$ With respect to interdependence, Herbert Spiro gives the following analysis:

Interdependence may be positive, as in the division of labor, or negative, as in nuclear deterrence. Interdependence varies also with regard the substance of the goods involved in the relationship, from labor, flows of communications, travel and migration, and other human goods, through commodities and other economic goods, to hostile, warring, or mutually supportive weapons systems. ${ }^{10}$

Interdependence should be contrasted from integration in that interdependence, which implies the balance of acquired positions, both at the national and international level, has a more static connotation. ${ }^{11}$ The concept of integration applies both to national politics, in the form of socio-political integration required by the functioning of modern societies, and to international politics, in the form of the supranational solution to the problems that are encountered by single nation states. Moreover, integration applies to conflicts of interests that may arise between the different actors involved. ${ }^{12}$ It is this double dialectic of integration that makes it more comprehensive and dynamic as a concept, since it describes two processes linked together in a constant evolution towards

\footnotetext{
${ }^{7}$ Joseph A. Camilleri, 1992: 29.

${ }^{8}$ Ibid.

${ }^{9}$ Herbert Spiro, 1974: 147-8.

${ }^{10}$ Ibid. Spiro adds that complex interdependence can involve various members of a network repetitively in its interactions only, or non-repetitively in several overlapping networks.

${ }^{11}$ Ionescu, 1974: 22-23. My italics.

${ }^{12}$ Ibid.
} 
greater coherence. ${ }^{13}$ It is still noteworthy, however, that an opposite process to internal and external integration has been occurring in several regions where relations are fragmented and the sovereign exercise of power by a state becomes illegitimate in the eyes of a certain region or national minority. ${ }^{14}$ Not all states are adequate vehicles of nationalist claims. "Many "nations" (as self-conscious ethnic units) are "entrapped" within a sovereign space administered by a government that is controlled by a different nation. Such a state may be autonomous vis-à-vis the external world, but its internal legitimacy is constantly subject to interrogation, if not assault, by assertive national minorities."15

In discussing concepts such as interdependence and integration, it is deemed necessary to analyze some interpretations of the nature of sovereignty in the present context of international relations. The notion of sovereignty has more generally expressed the idea that there is a final and absolute authority in the political community and that no final absolute authority exists elsewhere. ${ }^{16}$ Like integration, sovereignty has both an internal and external dimension. Internal sovereignty connotes the exercise of supreme authority within the state's boundaries, whereas external sovereignty connotes the legal equality of states, with no state subjecting itself to a higher external authority. "Supremacy within and equality of status without are considered complementary and

\footnotetext{
${ }^{13}$ Ibid. Ionescu insists that of the three concepts of sovereignty, interdependence and integration, which are bound to coexist for a long time in the contemporary political world, integration has a more global connotation, and is as a result more comprehensive and dynamic than the other two.

${ }^{14}$ For example, the manner in which the former Soviet Republics split up, Yugoslavia during the course of this decade and the very interesting case of Colombia whose central government does not have control of part of that country's territory yet this country is a full member of the Andean Community, a regional economic bloc. While such occurrences are prevalent and destabilizing, a thorough analysis of crises of this nature is beyond the scope of this work.

${ }^{15}$ Richard Falk, 1990: 62. His quotations.

${ }^{16}$ Hinsley, 1986: 1.
} 
mutually reinforcing manifestations of sovereign statehood."17 The external (international) function of the state is inseparable from the internal (societal) one. ${ }^{18}$

Geoffrey L. Goodwin argues that although the concept of sovereignty can be given several meanings, the most helpful is to treat it as an absolute and not a relative concept. "In principle, it can only be one thing or another. If it is not separate and supreme in constitutional terms, it lacks sovereignty." 19 The operative word is principle; and in principle, Goodwin is correct in stating that sovereignty cannot be eroded, only extinguished. ${ }^{20}$ In practice, however, sovereignty is a relative term, and governments are in a constant process of negotiating the state's sovereignty. ${ }^{21}$ Furthermore, as the nature of the state changes, due to processes such as globalization that may be altering the scope and nature of the state in both its internal and external relations, the relativity of the practice of sovereignty becomes apparent. Hence, the relationship between sovereignty and the state becomes critical in trying to comprehend the relative/absolute dichotomy surrounding the concept of sovereignty. F H. Hinsley offers the following summary of the traditional relationship between sovereignty and the state:

The concept has been formulated when conditions have been emphasizing the interdependence between the political society and the more precise phenomenon of its government. It has been the source of greatest preoccupation and contention when conditions have been producing rapid changes in the scope of government or in the nature of society or in both. It has been resisted or reviled - it could not be overlooked - when conditions, by producing a close integration between society and

\footnotetext{
${ }^{17}$ Joseph A. Camilleri and Jim Falk, 1992: 139.

${ }^{18}$ Ibid.

${ }^{19}$ Goodwin, 1974: 115. His Italics.

${ }^{20}$ Ibid.

${ }^{21}$ See Thomas J. Biersteker and Cynthia Weber 1996: 9-13. My italics. On page 11, they state that "rather than proceeding from the assumption that all states are sovereign, we are interested in considering the variety of ways in which states are constantly negotiating their sovereignty." See also Roxanne Lynn Doty 1996: 122. For example, Doty argues that practitioners of statecraft are ardently and continuously involved in the construction of the nation.
} 
government or else producing a gap between society and government, have inclined men to assume that government and community are identical or else to insist that they ought to be. In a word, the origin and history of the concept of sovereignty are closely linked with the nature, the origin and the history of the state. ${ }^{22}$

States are not necessarily any less sovereign because they do not possess complete freedom of action. ${ }^{23}$ "There is now considerable evidence, especially in the light of recent trends, that international and transnational interaction is central to the organization and distribution of economic and political power and greatly compounds the already considerable ambiguity surrounding at every level the principle of sovereignty. ${ }^{9} 24$

With respect to integration, an integrated community can mobilize much larger capabilities for a wide range of different goals. ${ }^{25}$ "In other words, integration - and more particularly political amalgation - aims at the creation of a wide range of general purpose capabilities, often exceeding by an order of magnitude or more the capabilities of the component states." ${ }^{26}$ Hence, the problem that states encounter in their practical loss of capabilities in the face of the divergent demands that are placed upon it seems to be resolved by integrating with other societies. Integration at the regional level is the main interest of this project, and the possible consequences that regional economic integration can have on the strategic outlook of the region.

\section{SECURITY and REGIONALISM}

In the era of economic transnationalization states are severely restricted in their capacity to manage their domestic economies by the actions of other

\footnotetext{
${ }^{22}$ Hinsley, 1986: 2.

${ }^{23}$ Ibid. p. 24. Camilleri quotes Hinsley.

${ }^{24}$ Ibid. p. 26.

${ }^{25}$ Deutsch, 1974: 181. Regarding

${ }^{26}$ Ibid.
} 
states, more importantly by the behavior of non-state actors, perhaps most importantly by the rapidly evolving structure of the world economy. ...Similar trends, albeit in more subtle form, are at work in the security field where the state has traditionally prided itself on being the architect of policy and on exercising a monopoly on the use of force. ${ }^{27}$

The state operates in a complex environment in which policy decisions, processes and outcomes cut across state boundaries and in which the pattern of authority corresponds less to the system of sovereign states, as has traditionally been the case. ${ }^{28}$ If the current capitalist world economic structure is seen as being mainly responsible for regional integration, then what is mainly responsible for current transnational trends in the security field? In order to answer this question it becomes necessary to determine a working definition for security, and how this definition has been altered after the Cold War. An adequate definition for regionalism is needed as well.

The concept of security is politically powerful, weakly conceptualized and increasingly contested. Ramesh Thakur contends that three questions may be raised by way of preamble:

- Who are the referents of security: for whom is security intended - individuals, groups, nation, state, region, world?

- What are the instruments of security: by what means is security to be achieved military, nuclear, political, diplomatic, economic?

- What are the costs of security: at what price to the economy and to social and political values can security be achieved? ${ }^{29}$

${ }^{27}$ Camilleri and Falk, 1992: 139.

${ }^{28}$ Tbid.

${ }^{29}$ Ramesh Thakur, 1997: 52. 
The answers to these questions have changed since the end of the Cold War. ${ }^{30}$ For instance, the concept of security has been broadened considerably to incorporate issues outside of the military realm. This includes political, societal, economic and environmental dimensions. "Moreover, the several dimensions are not treated mechanistically, but holistically, with many linkages and some tension between them." If one is to treat these dimensions of security holistically, the border between the domestic and the international becomes increasingly irrelevant. Thakur suggests that we may be undergoing a radical conceptual shift from national security, and its focus on the military defense of the state, to human security with its emphasis on the individual's welfare. $^{32}$ In this context, a distinction between the different levels of security becomes necessary. Eduardo Gamarra and Douglas Kincaid offer the following definitions:

By national defense, we refer to the upholding of the sovereignty of the national state and territory against external threats, usually although not exclusively emanating from other states. Public security refers to the maintenance of public order and the enforcement of laws. Citizen security concerns the guarantees of specific rights pertaining to citizens as such, including both civil and political rights. All three types of security, along with institutional responsibilities and jurisdictions, are usually spelled out in national constitutions and elaborated within legal frameworks. ${ }^{33}$

\footnotetext{
${ }^{30}$ Ibid. Thakur dates the end of the Cold War in the 1989-1991 period collectively, with the breaking down of the Berlin Wall in 1989, the reunification of Germany in 1990, the Gulf War (1990-1991), and the implosion of the Soviet Union in 1991.

${ }^{31}$ Ibid. pp. 52-53. Thakur briefly defines these different dimensions of security: Military security is seen as the defense of a state's citizens, territory and resources against external enemies. Political security involves protection the organizational stability of states, systems of government and their legitimizing ideologies. Economic security entails the maintenance of given levels of welfare and state power through access to resources, finance and markets. Societal security concerns the maintenance of traditional patterns of language, culture, religion, social order and communal identity within the context of evolutionary change. Environmental security means the sustainability of natural ecosystems. My italics. Thakur cites Barry Buzan's definition of military security. See also in Barry Buzan, 'New Patterns of Global Security in the Twenty-first Century', International Affairs, vol. 67, no.3, July 1991, p. 433.

${ }^{32}$ Ibid. p. 53.

${ }^{33}$ Douglas Kincaid and Eduardo Gamarra, 1995: 2. My italics.
} 
With respect to regional security, Muthiah Alagappa points out that two related

developments may explain the current interest in security regionalism:

1. The regionalization of international security brought about by the termination of the Soviet-American conflict and the ongoing changes (economics driven but accelerated by the collapse of the former USSR) in the distribution of power. In the absence of an overarching and overriding global-level security dynamic, domestic, bilateral and regional dynamics of conflicts may become more salient and must be addressed on their own terms.

2. The two global actors - the United States and the United Nations - have neither the resources nor the political will to become involved in security problems in all areas of the globe. ${ }^{34}$

These two developments require regional states to assume greater responsibility for their own security. Alagappa defines regionalism as "sustained cooperation, formal or informal, among governments, non-governmental organizations or the private sector in three or more contiguous countries for mutual gain."35 Regarding the advantages and disadvantages of regional organizations in the security sphere, Ramesh Thakur summarizes that:

\footnotetext{
${ }^{34}$ Alagappa, 1995: 152-3. On page 154, Alagappa cites a report prepared on UN peacekeeping in the postCold War era, where former Secretary General Boutros Boutros Ghali made the following statement: "the security council has and will continue to have primary responsibility for maintaining international peace and security, but regional action as a matter of decentralization, delegation and cooperation with the United Nations could not only lighten the burden of the Council, but also contribute to a deeper sense of participation, consensus and democratization in international affairs." See also Boutros Boutros Ghali, Secretary General of the United Nations, An Agenda for Peace: Preventative Diplomacy, Peacemaking, and Peace-Keeping, United Nations, 1992, pp. 36-7. With respect to the United States, a case in point may be President Clinton's attitude towards the East Timor Crisis in Indonesia. When speaking to the press about it, he emphasized on several occasions that the U.S. role should be minimal (logistical support) and applauded efforts by Indonesia's neighbors, particularly Australia's role as mediator in the crisis. C-SPAN, 9-9-99

${ }^{35}$ Ibid. p. 158. Alagappa cites the following definitions of regionalism: Joseph Nye states that regionalism 'in a descriptive sense' is 'the formation of interstate associations or groupings on the basis of regions', with regions being defined 'as a limited number of states linked by a geographical relationship and by a degree of mutual interdependence'. See also International Regionalism, Little, Brown and Company, Boston, 1968, p. vii. Donald J. Puchala and Stuart I. Fagan define regionalism as 'a collection of procedures and techniques, set in particular attitudinal environments, by which governments and peoples maximize mutual positive payoffs by exploiting their mutual interdependence'. See also in 'International Politics in the 1970s: The Search for a Perspective', International Organization, vol. 28, no.2, Spring 1974, p. 259.
} 
Regional organizations would have the advantages of closeness to the conflicts, deeper familiarity with the issues underlying the conflict and the social and political contexts encasing them, and awareness of the urgency to deal with the crisis at hand. The handicaps under which regional arrangements operate include local rivalries, partisanship, the tendency to replicate local power imbalances within the regional organizations, and the fear of establishing precedents for intervention in the internal affairs of member countries. ${ }^{36}$

A partial answer to the question of what is responsible for current transnational trends in the security field appears to be that increasing regional economic interdependence, coupled with the impact of the end of the Cold War, often results in cooperation in other areas such as security. While the implications of regional economic interdependence should not be exaggerated, the development of policy networks, which result from interdependence, can have an important influence on politico-security relations. $^{37}$ Generally, economic interdependence results in increased links between societies and gains by many, but not all, of those involved in the transactions. "Thus, economic interdependence and growth have complex and contradictory implications for political relations and national security."38

While the potential exists that increased economic interaction enhances security, it may also serve as a source of disputes since interdependence can create vulnerabilities. ${ }^{39}$ This is an important point to keep in mind as integration experiments in the developing world such as MERCOSUR are analyzed. In this context, cooperation

\footnotetext{
${ }^{36}$ Thakur, 1997: 71.

${ }^{37}$ Charles E. Morrison, 1997: 123.

${ }^{38}$ Ibid. p. 129.

${ }^{39}$ Andrew Mack and Stuart Harris, 1997: 10. On page 19, they state that "interdependence may enhance security traditionally defined (that is, the absence of interstate war), while at the same time providing new instruments of coercion for the powerful to wield against the weak." This is an important point given the uneven relations that often occur in the context of economic integration experiments.
} 
becomes a relevant concept. According to Robert Keohane, "cooperation should not be viewed as the absence of conflict, but rather as a reaction to conflict or potential conflict." ${ }^{90}$ Cooperation occurs when the policies implemented by one government are viewed by its partners as the realization of their own objectives. ${ }^{41}$ Regarding intergovernmental cooperation and its goals, Alagappa offers the following summary:

The goal of cooperation may be the facilitation of orderly interaction in a given issue area, resolution of a substantive problem, collaboration to enhance a set of values, or the power and influence of the collection in its interaction with other states and organizations, all with the ultimate purpose of enhancing the national well-being of participating states. ${ }^{42}$

According to this reasoning, cooperation can embrace a wide range of activities that include collaboration, coordination and even integration in some issues areas, but not political unification. "Cooperation under the label of regionalism is usually wide ranging in terms of issue areas as well as goals, and it has a long time horizon."

\section{THE END OF THE COLD WAR: THE CASES OF WESTERN EUROPE AND THE ASIA-PACIFIC REGION}

\section{THE EUROPEAN UNION AND SECURITY}

Whereas previously, both prior to the nuclear age and throughout the Cold War, it was simple to define and plan for the protection of 'vital national interests', in the post-Cold War world such threats and risks as do exist are thought to stem above all from indirect causes such as economic chaos, social and demographic instability and their attendant political upheavals. $^{44}$

\footnotetext{
${ }^{40}$ Robert O'Keohane, 1984: 54.

${ }^{41}$ Ibid. pp. 51-2.

42 Alagappa, 1995: 158.

${ }^{43}$ Ibid.

${ }^{44}$ Jolyon How orth, 1997: 28. His quotations. Writing about France, Howorth points out that "the principal sources of tension in the post-Cold War world are now seen in France as stemming from disequilibria between the rich areas of the world and the poor. Interdependence is perceived not simply as a feature of
} 
Highlighting the new European discourse is a conceptual shift from defense policy and its overwhelming emphasis on military dimensions to a "broader understanding of security which embraces economic and industrial policy as well as diplomatic, cultural, educational and other dimensions." 45 The transformation of the post-Cold War political order has required both a reconsideration of the nature of security and of the threat posed to the Western European countries. ${ }^{46}$ While the terms security and military security were generally used interchangeably during the Cold War, since then the content of security has been broadened making security a much more ambiguous concept. ${ }^{47}$ In the present transition period the rationales of the old security order are no longer relevant, but a new security order has yet to emerge. ${ }^{48}$ Reimund Seidelmann argues that European policies face a three stage challenge:

1. Elaboration of a grand design for the new order.

2. Organization of political support for the design within and between European countries.

3. Implementation of the design in terms of operational institutions and mechanisms and terms of common political will, values and identity. ${ }^{49}$

At this stage, the role played by institutions becomes important. Of concern is that the majority of European international organizations were developed in the aftermath of the Second World War and during the Cold War, and that these were developed to address the challenges of those times. Today's problems and geographic focus are

the economic and industrial systems of the advanced market economies, but also as a desirable foundation for regional and international stability." Ibid.

${ }^{45}$ Ibid.

${ }^{46}$ Emil Kirchner, 1995: 1.

${ }^{47}$ Ibid. Kirchner points out that the NATO alliance has acknowledged that political, economic, and even environmental concerns are displacing the military mission of the alliance. Ibid.

${ }^{48}$ Reimund Seidelmann, 1995: 114.

${ }^{49}$ Ibid. 
different. $^{50}$ There is uncertainty as to which organizational framework should take precedence in efforts by Western European countries to confront threats posed by the altered post-Cold War international and regional environment. In the present European era, the challenge of ethnic conflict in Eastern Europe and the objective of union building in Western Europe are intertwined. "The character and scope of the new conflicts in Europe, and the circumstances under which they have come about, had an impact on the rationale of Western European integration." ${ }^{51}$ As pertaining the security role of the European Union (EU) in this new context, Reinhardt Rummel poses that:

In many ways the response to potential conflict on their doorstep has been a cold start for the west Europeans and their collective organizations. As the EU, which was designed to cope primarily with controversies and conflicting interests among its member states, moved into a position of conflict management in Eastern Europe, a new type of policy mix was required, new internal structures of decision-making, and a new level of international sharing of responsibilities. ${ }^{52}$

Those demands strengthened the idea of enriching the external component of the European Community and of establishing a political union along with the economic union. The Maastricht Treaty, in force since November 1, 1993, establishes the European Union and codifies that idea. ${ }^{53}$ Among the proposed goals of the Maastricht Treaty is the implementation of a security policy, including the eventual framing of a common defense policy. "The Union is to request the Western European Union (WEU), which is

\footnotetext{
${ }^{50}$ Abram and Antonia Handler Chayes, 1996: 7.

${ }^{51}$ Reinhardt Rummel, 1996: 197. In Michael Welsh, 1996: 136, former European Community President Delors is quoted on a speech made to the Institute of Strategic Studies in March 1991 as saying that "the only option compatible with the complete vision of European Union is to insert a common security policy into this framework... We must make it clear that what we are proposing is a single community as a logical extension of the ambitions of European Union heralded by the Single European Act." Alastair Buchan Memorial Lecture, March 7, 1991.

52 Ibid. pp. 197-8.

${ }^{53}$ Ibid. p. 198.
} 
recognized as the military arm of the EU, to elaborate and implement decisions and actions of the Union that have defense implications." Europeans have been more prone to think in terms of equipping Europe with a defense capability of its own. The changes that have occurred since 1989 has removed the allencompassing threat facing Western Europe and has enabled other groups to influence policy outcomes, "hence placing defence issues back within the framework of legitimate political debate and dispute." 55

The Maastricht agreements establish the common recognition of the WEU as an essential element of the union and that it should be viewed as a link between the EU and the Atlantic Alliance. These agreements recognize that Europe's defense can no longer simply depend on the U.S. dominated NATO alliance, and that the WEU offers a way out of this. ${ }^{56}$ The empirical reality, however, provides qualification to such optimism. Despite the rhetoric of the EU treaty, progress in the defense sphere has been minimal. "Moreover, to the extent that defense does come within the ambit of integration, the pillared structure created in the Maastricht Treaty ensures not only that member states take decisions by unanimity, but also that the supranational institutions have only a very

\footnotetext{
${ }^{54}$ Ibid. pp. 200-1. Rummel poses that the provisions on defense are potentially important innovations in the security sector of the unification process, though they will certainly need further qualification given the new range of security tasks after the end of the Cold War. Ibid. It is worth noting that the WEU is a European defense alliance founded in 1948, a year before NATO. Its operational responsibilities were soon after transferred to NATO and it became a dormant organization. The WEU was reactivated in 1986 and has since been developed as the European pillar of NATO. This organization has been found as the most acceptable European defense institution to the U.S and the U.K. because it has no formal linkage with the European Union. Moreover, in 1990, the French Prime Minister and German Chancellor agreed that an organic link should be established between the WEU and the European Political Union (EPU). "One consequence of the Franco-German proposal was a set of principles outlining a common foreign and security policy (CFSP) in the draft treaty for European Political Union that included, inter alia, the designation of the WEU as the operational arm of EPU in defence related matters." Emil Kirchner, James Sperling and Christoph Bluth, 1995: 13. See also in Michael Welsh, 1996: 3.

${ }_{55}$ Anand Menon, 1997: 5-6.

${ }^{56}$ Michael Welsh, 1996: 139.
} 
minor, consultative role to play." 57 The point to keep in mind here is that the direct role played by the EU over national defense policy in its member states has been minimal, and that European supranationality does not at this time apply to issues of national defense.

The EU has had an indirect impact on national policies, however. European Union policies in areas other than defense have impinged on national defense policies. For example, in order to meet the stringent criteria for monetary integration by 1998 , and in the absence of the Cold War, armaments programs have been cut back and armed forces have been reduced in size throughout the EU countries. "Another way in which the EU may have impacted indirectly on national policies is through the increased links it has fostered between states in non-military areas." $" 58$ The EU may play a role in broadening concepts of security, altering the relative weight accorded to questions of purely military security to perhaps facilitate military cooperation. Moreover, U.S. reluctance in involving its military abroad, coupled with shrinking defense budgets among European countries places a lot of pressure on single countries to achieve security objectives alone. ${ }^{59}$ Freedman and Menon posit that while it may be tempting to assume then that the EU will increase its role in defense issues, there are two reasons against defense cooperation within the EU ambit. First is that states have displayed a tendency to choose cooperative projects that limit the impact on national autonomy; secondly, EU involvement in security issues has been limited due to alternative institutional structures

\footnotetext{
${ }^{57}$ Lawrence Freedman and Anand Menon, 1997: 156.

${ }^{58}$ Ibid. pp. 156-7.

${ }^{59}$ Ibid. pp. $157 \& 160$.
} 
that have been efficient and acceptable as cooperative mechanism, such as NATO. ${ }^{60}$ They explain that:

It would be incorrect to view the failure to achieve more within the EU framework as indicative of a failure to respond to increasing pressure on the state by practical steps towards enhanced institutionalized cooperation and even integration. This has taken place within NATO. For the most committed, however, the European project cannot be considered complete until defence is fully included. ${ }^{6}$

The comfort that Western European countries had in security cooperation within the aegis of NATO appears to be over in light of the recent Kosovo war. On June 3, 1999 the leaders of fifteen European countries decided to make the EU a military power for the first time in its history, with command headquarters, staffs and forces for its own peacekeeping missions in future crisis like the one in Kosovo. According to a plan announced at the European Union summit in Cologne, Germany, by late 2000 a single foreign and security policy czar will speak for Europe and carry out the will of European leaders. $^{62}$ All fifteen leaders declared that "the union must have the capacity for autonomous action, backed up by credible military forces, the means to decide to use them, and a readiness to do so, in order to respond to international crises without prejudice to actions by NATO." ${ }^{963}$ Logically, the European leaders decided to utilize the WEU and its 60,000 troops, Eurocorps. The Eurocorps, they added, would be put at the disposal of the new, more assertive Europe that is taking shape under the EU. ${ }^{64}$ It would seem then that a relationship between economic integration and security cooperation

\footnotetext{
${ }^{60}$ Ibid. p. 161.

${ }^{61}$ Ibid. p. 162.

${ }^{62}$ New York Times, 6-4-99, European Union Vows to Become Military Power.

${ }^{63}$ Ibid.

${ }^{64}$ Ibid.
} 
exists in the context of the European Union and as a result of crises that have occurred in an altered post-Cold War international structural environment.

\section{THE CASE OF ASIAN-PACIFIC COOPERATION}

Asian diplomacy, it is said, rests on reaching consensus between competing interests; the idea of majority voting to resolve disagreements is generally unacceptable. There is substantial evidence that Asian states strongly prefer informal means of collaboration rather than the building of elaborate institutional frameworks. Premature attempts to impose institutionalisation on the region may be counterproductive. ${ }^{65}$

In the Asia-Pacific region, economic interdependence seems to have been more a consequence of reasonably good political relations than a cause of them. ${ }^{66}$ Recently, different types of multilateral networks have developed in the region. Some of these networks are in the form of formal inter-governmental institutions (such as ASEAN, APEC and the ASEAN Regional Forum), while others are overlapping 'second track' networks, "intended to identify issues and develop solutions or means of coping to bring to the attention of the formal governmental processes." ${ }^{, 67}$ This process of institution building arose first in the economic realm due to the sensitivities of the politico-security realm. ${ }^{68}$ U.S. and Chinese interests in the region were tantamount, and the smaller Asian nations tittered between two powerful and ideologically opposed hegemonic powers. Interestingly, and in that context, economics (and dealing with issues of interdependence)

\footnotetext{
${ }^{65}$ Mack and Ravenhill, 1995: 14.

${ }^{66}$ Morrison, 1997: 130.

${ }^{67}$ Ibid. p. 131. APEC is the acronym for the Asian-Pacific Economic Cooperation.

${ }^{68}$ Ibid. p. 132.
} 
to a great extent served as a cover for those actors who wanted to involve themselves in political activity, but that could not explicitly state that this was the case. ${ }^{69}$

During the Cold War, the focus in the Asia-Pacific region most generally regarded domestic security issues. Domestic threats were considered more serious than external threats since the most pressing challenges that the newly independent states of Southeast Asia had to deal with were ethnic separatism and communist insurgency. ${ }^{70}$ With respect to cooperation, "the idea that pursuing economic engagement/enmeshment strategies with adversaries, or potential adversaries, might be security-enhancing was not taken very seriously in the Cold War era." ${ }^{91}$ The Cold War, coupled with the desire of the communist regimes in China, North Korea and Vietnam to be self-reliant, ensured that interdependence between these countries and the pro-Western nations in the region

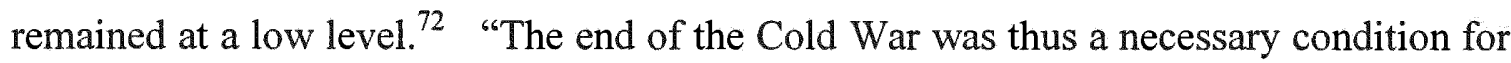
the building of region-wide regimes in both the economic and security spheres."73 In this context then, "APEC can be seen not just as an economic organization, but as a post-Cold War strategic partnership or link between Asia/Western Pacific and North America."74

\footnotetext{
${ }^{69}$ Ibid. The Association of East Asian States (ASEAN) was created in 1967 by negotiations involving mainly government officials from the member countries. The original membership includes: Brunei, Indonesia, Malaysia, the Philippines, Singapore and Thailand. Recently, Vietnam has become a full member. Morrison points out that "the key function of the new association was to cement a relationship between the 'New Order' government in Indonesia and the more Western-oriented countries that were already engaged in a cooperation scheme, the Association of Southeast Asia, comprised of Malaysia, the Philippines, and Thailand." Ibid.

${ }^{70}$ Amitav Acharya and Richard Stubbs, 1999: 123.

${ }^{71}$ Stuart Harris and Andrew Mack, 1997: 1.

${ }^{72}$ Andrew Mack and John Ravenhill, 1995: 4.

${ }^{73}$ Ibid. Mack and Ravenhill point out that the dramatic growth in interdependence in the region, which saw intraregional trade reach levels like those of the EU, happened (with the exception of ASEAN) in the absence of organizations designed to reduce transaction costs. They argue that this reinforced demands for the negotiation of these type of arrangements. Ibid. p. 5 .

${ }^{74}$ Morrison, 1997: 134-5. He points out that to a great extent, the ideas behind APEC came into being through the operation of policy networks that were focused on issues arising out of interdependence, key among these the conflictual elements such as U.S. - Japan trade conflicts.
} 
In the post-Cold War era, engagement is central to the security policies of the U.S. and most regional states towards China, for example. Now, there is an increasing interest in the security implications of economic interdependence. ${ }^{75}$ This ties into Keohane's argument that cooperation should not be viewed as the absence of conflict, but as a reaction to conflict or potential conflict. ${ }^{76}$

In the post-Cold War era, many of the internal sources of instability have lessened since rapid economic growth has reduced the possibilities of domestic challenges to regime legitimacy. ${ }^{77}$ At the present time, the Asia Pacific countries perceive the region's shifting balance of power as the principal source of threat. "Southeast Asia's leaders have expressed concerns that the end of the cold war order could be followed by strategic competition among a host of powers, including conflicts previously suppressed by superpower rivalry."78 Moreover, interdependence (as seen by the growing irrelevance of borders) is less evident in the region that in Europe, for instance. This may be the case since regional economic integration is less advanced in East Asia than in other parts of the world, and because of the relatively recent emergence of these countries from colonialism and neo-colonialism. ${ }^{79}$ In practice, however, concerns with sovereignty have not prevented these states from pursuing integrating economic policies, nor from supporting regional organizations like APEC and the ASEAN Regional Forum (ARF). ${ }^{80}$

\footnotetext{
${ }^{75}$ Mack and Ravenhill, 1995: 2.

${ }^{76}$ Robert O'Keohane, 1984: 54 . See citation on page 14 of this work.

${ }^{77}$ Amitav Acharya and Richard Stubbs, 1999: 123. The authors add that "there has been a shift in the traditional inward-looking view of security in the region. Now, external threats to national security are receiving more attention, with a corresponding shift in their security posture from counter-insurgency to conventional warfare." Ibid.

${ }^{78}$ Ibid.

${ }^{79}$ Stuart and Mack, 1997: 8.

${ }^{80}$ Ibid. The ARF is a broad regional ministerial level dialogue on security issues, which has adopted the APEC (Asian-Pacific Economic Cooperation) and ASEAN formula of interim senior official meetings and
} 
The Asian Pacific Economic Cooperation forum was established at a ministerial meeting in Canberra, Australia on November $1989 .{ }^{81}$ APEC has been the only formal region-wide multilateral organization that deals with economic issues. While it has resulted in greater interaction between the member economies and has seen some institutionalization, this organization lacks clear dispute settlement mechanisms to resolve conflicts. "In good part this is because of divisions along North-South lines which have undermined the prospects for a clear consensus on the way forward for APEC." ${ }^{\prime 2}$ For example, the East Asian Economic Caucus (EAEC), which includes the Asian members of APEC, has been incorporated into APEC but it is possible that it could compete with APEC at some point in time. ${ }^{83}$

As regards cooperative security, the ARF is a pretty unique regional security institution. Despite the fact that it has a strong representation from 'northern' countries, agenda setting has been controlled by the developing states. ${ }^{84}$ Unsurprisingly, within the ARF there are key differences between its Western and Asian members. For instance, Australia and Canada call for rapid progress by the ARF in developing concrete measures

a work program. ARF emerged out of policy recommendations from the ASEAN-ISIS group, which is a consortium of security and political economy oriented policy research institutions and involves public as well as private sector input. Morrison, 1997: 133-135.

${ }^{81}$ Acharya and Stubbs, 1999: 130. APEC membership includes the ASEAN states of the time - Brunei, Indonesia, Malaysia, the Philippines, Singapore, and Thailand - and Australia, Canada, Chile, China, Hong Kong, Japan, Mexico, New Zealand, Papua New Guinea, South Korea, Taiwan, and the U.S.

${ }^{82}$ Ibid. The authors give as an example the U.S., Australian and Canadian intentions of using APEC as a form in they can tie in as many regional economies as possible into an open, market-led, regional arrangement that would undercut any trend toward protectionism in the global economy. Japan's opposing view is that APEC should hold discussions and policy dialogues, attempt to develop a common understanding on how to strengthen regional cooperation, and help with policy-making at the regional and national levels.

${ }^{83} \mathrm{Ibid}$. The EAEC is likely to emerge as an important forum for regional integration since these countries share aspects of recent history, similar values and common approaches to their economies. Ibid. pp. 130-1. ${ }^{84}$ Ibid. pp. 131-2. The ARF was established in July 1994. Its membership includes the seven ASEAN states, Australia, Canada, China, the EU, Japan, Laos, New Guinea, New Zealand, Papua, South Korea, and Russia. 
of security cooperation. Conversely, "the ASEAN states have adopted a much more gradual, informal, and cautious approach to institution-building and explicitly rejected the need to emulate Western models of security cooperation." ${ }^{85}$ In light of these differences, it is questionable whether the ARF will able to provide practical solutions to regional security problems. ${ }^{86}$ It is safe to say that it is much more difficult to come to a consensus on issues that posit key fundamental differences in the viewpoints of member states of organizations like APEC and ARF. This, it can be argued, is especially the case at the broad regional level of APEC, which includes members from four different continents. At the sub-regional level (ASEAN for example), economic integration and security cooperation may be more attainable. Moreover, even though the apparent purpose for establishing ASEAN was the promotion of economic, cultural and social cooperation of its members, "its principal functions in the first quarter century of its existence were related to the internal and external security of its member states." ${ }^{.77}$

With respect to linkages between the economic and security dimensions, a direct relationship appears to exist between these dimensions in the current post-Cold War environment of the Asia-Pacific region, particularly among the ASEAN states. It can certainly be argued that a security community has been built in the ASEAN states, for whom the non-use of force has become a norm in their relations. ${ }^{88}$ Even though some have suggested that APEC be expanded to the security realm out right, this is not likely

\footnotetext{
${ }^{85}$ Ibid. p. 132. Moreover, the authors point out that China and the ASEAN states believe that the ARF should not develop into a forum for promoting human rights and democracy because this will lead to the interference of Western powers in their internal affairs. Ibid.

${ }^{86}$ Ibid.

${ }^{87}$ Mack and Ravenhill, 1995: 3.

${ }^{88}$ Morrison, 1997: 133. According to Morrison, the expansion of ASEAN to include Vietnam, and eventually the three remaining Southeast Asian countries that are non-members, "has logic from a political
} 
due to the membership of the Chinese Taipei, and the existence of ARF, which does deal explicitly with security issues. ${ }^{89}$ Even though the limitations of ARF (the diversity and number of its members for one) have been pointed out, this exercise has shown a relationship, albeit an ambiguous one, between economic integration and security cooperation in the Asia-Pacific region. A parallel could be drawn between the difficulties of achieving more in the way of institution building within APEC, and the limited progress that has been achieved in enacting the free trade area of the Americas proposal, which was agreed upon by the 34 democratically elected nations of the Western Hemisphere in 1994. A parallel could perhaps be drawn as well between MERCOSUR and the ASEAN region, which has shown that progress in economic integration and security regionalism may be more feasible at the sub-regional level. The preference for informal negotiations and the consensus basis for decisions by the Asian countries is also relevant. As will be pointed out in the next chapter, this is the predominant Brazilian stance regarding negotiations in the MERCOSUR, as shown by its rejection of supranational institutions in this organization.

and security perspective even if the broadening of ASEAN may become a drag on the deepening of economic, social, and cultural cooperation." Ibid.

${ }^{89}$ Ibid. p. 135. 


\section{CHAPTER 2}

\section{INTRODUCTION}

While cooperation in defense procurement and production might seem to run against the historical tide of secret arms races for superiority, it is likely that the security threats facing Latin America in the coming decades will demand not defense against neighboring armies, but cooperatively combating forces beyond one nation's control. ${ }^{90}$

This chapter will examine MERCOSUR and analyze the integrative politicaleconomic processes that have spurned this organization and the consequences that these processes have in the security arena. In this chapter, I will establish the following arguments, and these will be further developed in the ensuing chapters. First, the new political-economic context in the Southern Cone has led to fundamental changes in the security and strategic outlook of these societies. Second, that the eventual success of MERCOSUR depends in great part on the maintenance of the basic tenets of democracy in the region. In other words, without democracy in the Southern Cone there is no MERCOSUR. Political-economic convergence coupled with transnational threats to security, are forcing nations to cede varying amounts of sovereignty. Given that it will be argued that it is more beneficial for developing countries to formally consolidate and strengthen the institutions of existing regional organizations such as MERCOSUR so that these countries, limited resource-wise, can coordinate their policies to counter common threats. This argument is also based on the assumption that as a member of a regional organization, it is strategically more beneficial for a developing country to deal with other

\footnotetext{
${ }^{90}$ Patrice M. Franko, 1996:19.
} 
blocs collectively rather than on an individual basis. A corollary to this argument is that the lack of supranationality within MERCOSUR may be an impediment to the sturdiness of this organization in the long run and in the face of serious crisis situations in the region.

To properly put forth the above arguments this chapter will consist of four sections. First, I will provide a brief history of MERCOSUR. In doing so, the institutional characteristics of this organization will be explained given that many authors have argued that it is MERCOSUR's institutions (or lack of institutionalization) that limit the Southern Cone countries from becoming a full-fledged community, and common market. Hence, in relation to security cooperation between these countries, the formal juridical mechanisms that have been established within MERCOSUR are deemed relevant to an understanding of the potential breadth of this organization. Second, the altered, post-Cold War content of security and strategic issues in the Western Hemisphere will be analyzed.

The third part of this chapter will explore the security implications of politicaleconomic integration for the Southern Cone nations. The idea that economic integration is conducive to security cooperation comes into question as possible setbacks to the ongoing processes of integration occur. Also, current trends like the militarization of police functions will be discussed since they may threaten the process of democratization that these countries are undergoing. Lastly, this chapter will discuss proposals for the common security of the region. 


\section{MERCOSUR}

This renewal of the integration vocation undoubtedly has its roots in political change underway in the Southern Cone countries. The Latin American democratization process, spurning the national security doctrine, a loosening of the foreign debt tension, have all been factors with a positive influence on the renewal of this interest in integration and the renewed values attributed to its targets. ${ }^{91}$

It was the return to democracy in Brazil and Argentina that was the key element in their diplomatic rapprochement. A key step in deepening relations between these two countries was the signing of the Program for Integration and Economic Co-operation (PICE, or PICAB, which is the Spanish-Portuguese acronym) by Presidents Alfonsin of Argentina and Sarney of Brazil in $1986 .^{92}$ The main goal of the PICAB was to increase bilateral trade in order to improve both economies, thereby maintaining political stability in these two new democratic regimes. ${ }^{93}$ After the signing of the PICAB, a number of negotiations leading to the signing of the Treaty of Asunción ensued, the most important result being the Treaty of Integration and Economic Cooperation that was signed by Alfonsín and Sarney in Buenos Aires on November $1988 .{ }^{94}$ The goal of this treaty was to establish a customs union between Argentina and Brazil by the year 1999. Even though the Sarney-Alfonsin agreements brought neither economic nor political stability to their countries, they were instrumental in increasing and diversifying bilateral trade. "Furthermore, the inclusion in the PICAB of programs of cooperation in the nuclear

\footnotetext{
91 Jorge Lucángeli, 1998: 22.

${ }^{92}$ Peter Coffey, 1998: $4 \& 6$. This agreement comprised twenty-four individual sectors covering trade especially in capital goods, wheat and the automobile industry. It also included cooperation in technology and the supply of energy and other fields of activity.

${ }^{93}$ Thomas Andrew O'Keefe, 1993: 1.
} 
energy field contributed to greatly reducing tensions that had traditionally marked Argentine-Brazilian relations., 95

In July 1990 Carlos Menem and Fernando Collor de Mello, the respective presidents of Argentina and Brazil, signed the Buenos Aires Act, which proposed the creation of a common market between the two countries, otherwise known as Mercosur. The Mercosur called for the establishment of a common market by the target date of 1995 , as opposed to 1999 , as was delineated by the 1988 Alfonsín-Sarney agreement. ${ }^{96}$ It is worth noting that the former agreement called for a customs union while the latter sought the more ambitious goal of establishing a common market.

The Asunción Treaty was signed by Argentina, Brazil, Paraguay and Uruguay on March 26, 1991. As in the Buenos Aires Act, this treaty called for the establishment of a common market, but with the inclusion of Paraguay and Uruguay. Paraguayan and Uruguayan fears that they would be shut out of an integrative process involving their two largest trading partners led these two countries to seek inclusion into the process. ${ }^{97}$ For political and economic reasons it would have been unreasonable for these two countries not to seek inclusion in an integrative process that could provide increased access to two very large markets for their goods and improve their international bargaining position in a globalizing economy. It is also noteworthy, and relevant to this project, that Paraguay was invited to join the MERCOSUR because of the return to democracy in that country.

\footnotetext{
${ }^{94}$ María Eugenia Mujica, 1997: 108. The main objectives of this treaty were the elimination of existing tariff and non-tariff barriers.

${ }_{95}$ O'Keefe, 1993: 1.

${ }^{96}$ Ibid. p. 2.

${ }^{97}$ Ibid.
} 
Jorge Lucángeli points out that the central objective set down by the Treaty of Asunción is the integration of member states through the achievement of the following goals:

- The free movement of goods, services and productive factors by, among other measures, the elimination of customs duties and non-tariff barriers and any other equivalent measures on the movement of goods.

- The establishment of a Common External Tariff (CET) and the adoption of a common trade policy for third party countries or group of countries and the coordination of policy stances adopted in regional and international economic and trade forums.

- The coordination of macroeconomic and sectoral policies between Member States: in fields that include foreign trade, agriculture, industry, fiscal and monetary policies, foreign exchange and capital movements, services, customs, transport and communications, and others to be agreed on, in order to ensure adequate competitive conditions between member states.

- The commitment to harmonize legislation of member countries in pertinent areas, to reinforce completion of the integration process. ${ }^{98}$

\section{INSTITUTIONAL CHARACTERISTICS OF MERCOSUR}

A free trade area consists of an entity that removes tariff and quota type restrictions on goods among the member states, and is the most basic form of integration. ${ }^{99}$ A customs union is made up of a free trade area with a CET regarding third countries. A common market combines these factors, plus the free movement of goods, services, labor, and capital, as well as the coordination of macroeconomic and sectorial policies and may require the harmonization of members' national legislations. "Total economic integration is similar to federal, state, or community relationships in that each of the relevant states retain certain powers while overarching economic and social

\footnotetext{
98 Lucángeli, 1998: 22-23.

${ }^{99}$ Jorge M. Guira, 1997: 16.
} 
policies, affecting the entity as a whole, reside in a binding, decision-making body with supranational authority." 100

The Asunción Treaty was not very specific regarding the institutional framework for the integration arrangement, or the rights and obligations created for the parties, which are the necessary provisions that explain how countries can create a common market. ${ }^{101}$ This treaty was designed as a transition agreement meant to be supplemented by later agreements that were to provide both the institutional structure of MERCOSUR and how the common market was to be established. "The Treaty of Asunción, therefore, established only a skeletal framework for the necessary institutions."

The first decision of the Common Market Council, which is the main political organ of Mercosur, was to approve the interim dispute settlement system proposed by the Brasilia Protocol to the Asuncion Treaty. Following the Brasilia Protocol, the next major agreement was the signing of the Protocol of Ouro Preto in 1994, which created the political institutions of the MERCOSUR and extended the transition period for the integration process up until the year 2006. The Asunción Treaty and the Protocol of Ouro Preto established the following Mercosur institutions:

1. The Council of the Common Market (CMC), which is the main political organ of Mercosur, in charge of the political aspects of the integration process. It is a decision-making body, which seeks to fulfill the objectives established by the Asunción Treaty and the final implementation of the Common Market.

2. The Common Market Group (GMC) is the executive body of MERCOSUR.

\footnotetext{
${ }^{100} \mathrm{Ibid}$. Regarding the definition of a common market see in http://embassy.org/uruguay/econ/mercosur/merc-003.html, p. 3.

${ }_{101}$ Cherie O'Neal Taylor, 1997: 53.

${ }^{102} \mathrm{Ibid}$. Taylor notes that seven articles of the treaty describe the two political institutions that were supposed to administer and implement the treaty during the transition period, which was to last until the end of 1994, the Council of the Common Market and the Common Market Group.
} 
3. The Trade Commission of MERCOSUR (CCM) is the organization charged with assisting the GMC. Its main responsibility is to oversee the application of the instruments of common commercial policy.

4. The Joint Parliamentary Commission (CPC) is the representative body of the Parliaments of the MERCOSUR countries.

5. The Social and Economic Advisory Forum (FCES) is the representative institution of economic and social sectors.

6. The Administrative Secretariat of MERCOSUR (SAM) is the operational support organism that is responsible for providing services to the other MERCOSUR bodies. $^{103}$

The Ouro Preto Protocol reincorporates the interim dispute settlement system instead of establishing a permanent dispute settlement system. ${ }^{104}$ This is significant because any free trade, customs union or common market agreement must have at the very least political institutions and a dispute settlement mechanism. ${ }^{105}$ The Ouro Preto Protocol does establish that the CMC, GMC and the CCM each have the power to make legislative decisions that are declared by the Protocol to be binding on the member states, yet, the institutions are not given supranational authority. Several articles of the protocol point out that the MERCOSUR institutions are to make decisions only by unanimous consensus. "The states are, therefore, responsible for incorporating the MERCOSUR decisions into their own legal systems." ${ }^{106}$ Regarding the importance of political institutions and dispute settlement Cherie O'Neal Taylor offers the following analysis:

The political institutions are necessary to allow the countries to reach decisions about how to implement the treaty obligations and objectives

\footnotetext{
${ }^{103}$ Embassy of Uruguay, 1998: 1. This document also states that the present institutional structure does not have an undefined duration and that when the member countries consider it timely, they will convene a diplomatic conference with the purpose of evaluating the institutional structure of MERCOSUR, as well as the scope of authority of each of the bodies. See also Mujica p.?

104 Taylor, 1997: 53-54. On page 53, Taylor states that according to Article 3 of the Asuncion Treaty, the parties were charged with adopting a permanent system for the settlement of disputes at some time during the transition period on the way to a common market.

${ }^{105}$ Ibid. p. 50. Taylor poses that the dispute settlement mechanism is needed to resolve disputes that may arise over the meaning and application of the agreement's legal obligations and objectives.

${ }^{106}$ Ibid. p. 56.
} 
and to oversee that implementation... A dispute settlement mechanism is crucial to the viability of an economic integration arrangement because the traditional method by which states resolve disputes is through negotiations... A well designed dispute system will inevitably be responsive to, and reflective of, the economic goals being sought (the depth of economic integration desired by the participating countries), the political constraints (limitations imposed by the governments or domestic politics of the participating countries), as well as perceptions about the proper role of international institutions. ${ }^{107}$

Taylor argues that the absence of any supranational institutional bodies in MERCOSUR can be traced to political limitations as well as perceptions about past Latin American integration efforts. The political limitations come from the domestic legal systems of the member countries and the political realities of MERCOSUR membership. For example, Argentina and Paraguay have constitutions that accept the possibility of a supranational legal order; the Brazilian and Uruguayan constitutions, on the other hand, do not accept supranational bodies. ${ }^{108}$ It is worth noting, however, that Uruguay is the biggest proponent of a supranational court within MERCOSUR, and is obviously willing to amend its constitution to allow this. Brazil could also amend its constitution but is unwilling to cede any sovereignty to supranational bodies. ${ }^{109}$ In this regard, Brazilian Minister-Counselor Leda Lucia Camargo argues that the absence of supranational bodies results in less costs, less bureaucracy, and therefore greater flexibility and speed in accommodating problems and differences that may arise between the member states. ${ }^{110}$ The participating countries originally expressed a preference for minimal institutionalism over the establishment of a regional bureaucracy. "The concern is that such a

\footnotetext{
${ }^{107} \mathrm{Ibid}$.

${ }^{108}$ Ibid. p. 57. Look also in Gira, pp. 17-8.

${ }^{109}$ Look in the Brazilian Federative Constitution, C.F. article 4 of 1988 constitution (1994 revised ed.).
} 
bureaucracy would not be closely linked to the political process in each country or the task of actually reducing trade barriers." ${ }^{111}$ This is the main Brazilian argument regarding its refusal of establishing supranational bodies in MERCOSUR, and it is unquestionable that Brazil, the most powerful member of MERCOSUR, would have the most to lose in moving from political negotiations to supranational institutions as a mechanism to resolve disputes. Therefore, the Brazilian decision is not necessarily based on a juridical argument (or the unconstitutionality of accepting supranational bodies), but on political reasons.

Until recently, Argentina stood against the idea of supranationality, yet this position has changed. The altered Argentine position states that MERCOSUR needs to be further institutionalized by establishing a Court that can respond to existing and future conflicts given that as relations increase and negotiations intensify, the possibilities for conflict will increase as well. Hence, according to this line of thought, an organism for the purposes of dispute settlement with supranational authority is deemed necessary. ${ }^{112}$ The present model for the resolution of conflicts that MERCOSUR follows is one based on political negotiations and the consensus rule. ${ }^{113}$ MERCOSUR lacks the component of supranationality that is needed to deepen integration, which means that the Mercosur is weak institutionally (as opposed to the European Union, for example). One could argue

\footnotetext{
${ }^{110}$ Leda Lucia Camargo, draft of key-note presentation at the Mercosur Conference: Convergence or Conflict?, November, 1998, p. 5.

111 Taylor, 1997: 57. See also Fedrerick M. Abbott, 1995, p. 176-177. Abbott states that the political power to actually make the trade policy changes necessary rests with the Executive branch in each MERCOSUR country. (citation as cited by Cherie O'Neal Taylor, 1997).

${ }^{112}$ Christian Torres, Editorial Continental, 03-03-1998.

${ }^{113}$ Camargo, 1998: 9. Camargo explains that all MERCOSUR bodies are governmental, not supranational institutions, and argues that the consensus rule increases the feeling of security since each country knows that no decision will be taken without its approval, and that when consensus has been reached all are
} 
further that the integration process in the Southern Cone is too dependent on the wills of those persons in power. ${ }^{114}$ Yet, the MERCOSUR was designed to reflect its member states' desire to achieve economic integration through political cooperation rather than institutionalism. ${ }^{115}$ Following this reasoning then, security cooperation (as opposed to common security, for example) may offer the most realistic parameters for strategic cooperation in combating common threats to security within MERCOSUR's present political-economic framework. $^{116}$

\section{THE NEW SECURITY CONTEXT OF THE WESTERN HEMISPHERE}

The great paradox is that the welcome disappearance of communism as a basic threat has created a conceptual crisis in strategic thinking. ${ }^{117}$

Security does not exist in relation to a predetermined set of specific conditions but instead as a term of reference to a sliding scale of greater or lesser threats that inevitably vary over time and space. ${ }^{18}$ The concept of security has traditionally dealt with negative security issues such as threats to sovereignty, borders and physical survival. Today, the concept also encompasses positive security such as economic security, housing, health care, education and environmental integrity. ${ }^{119}$ It must be added that the principal 'new' negative threats to national as well as public security in the Western Hemisphere are drug

committed to the decision. Moreover, she argues that in practice, the consensus rule encourages the four countries to search for means to overcome stalemates, and thus, requires creative bargaining.

${ }^{114}$ Mujica, 1997: 112.

115 Taylor, 1997: 56.

${ }^{116}$ I distinguish between cooperative and common security in pages 38 \& 39.

117 Richard Downes, 1996: 2. Quote by Cesar Gaviria, Secretary-General of the Organization of American States.

${ }^{118}$ Jeffrey Stark, North-South Issues, September, 1992: 1. Interestingly, Stark points out that the linguistic root of the word security, securus, means free from care.

${ }^{119}$ Ibid. p. 4. 
trafficking and terrorism. Latin American countries are limited resource-wise to address positive security concerns and it should be noted that in the present Latin American context, resources will most likely be spent first on combating security threats such as drugs, terrorism and rising crime. In sum, Jeffrey Stark provides three general postulates for the broadening of the definition of security:

1. Since democratic rule and constitutional procedures are the only available mechanisms by which the nation can express its security requirements, national security requires their preservation.

2. The provision of basic human needs must be part of any meaningful definition of national security.

3. More problematic, threats that meet the threshold of causing extra-constitutional, large-scale disruptions of social peace fall into the sphere of national security. ${ }^{120}$

The end of the Cold War and the collapse of the Soviet system coupled with the regional processes of re-democratization and the liberalization of markets in the Western Hemisphere have significantly affected the Latin American region. "Re-democratization has resulted in new types of relations and has shifted the balance between state and society, between economic forces and political actors, and between the armed forces and civilian authorities."121 Moreover, as democracy matures in Latin America, civilians have become fully engaged in the dialogue on the region's strategic priorities, traditionally considered the exclusive domain of the military, and are forcing a reexamination of the state's priorities, including the role of the military and resources allocated to support that role. ${ }^{122}$ Rojas Aravena suggests that if the region is to be reconstituted, regional cooperation will have to be achieved as a deliberate project.

\footnotetext{
${ }^{120}$ Ibid. p. 6.

${ }^{121}$ Rojas Aravena, 1994: 174

${ }^{122}$ Richard Downes, 1996: 1.
} 
Efforts aimed at achieving common security emphasize international over national means and peaceful means over threats of force. ${ }^{123}$

\section{COOPERATIVE SECURITY}

A conceptual distinction between the concepts of cooperative and collective security is necessary. Collective security implies that the nations, which form part of a community, must show credibility in defending each other. Cooperative security, on the other hand, means mutual adjustment for mutual gain. David Mares argues that cooperative security is more applicable to heterogeneous communities than common security. ${ }^{124}$ Given the lack of supranational institutional bodies in MERCOSUR cooperative security is clearly more applicable than common security since the term cooperation implies negotiation among distinct parties, for example, between foreign ministries. In this context, relationships can be mutually beneficial and aid in accustoming different state actors such as governments and militaries to engage in open dialogues and to coordinate different activities in their efforts to combat common threats.

It is possible to identify three trends which best describe the axes of security cooperation in the Western Hemisphere since the onset of the post Cold War era. Richard Downes offers:

1. Institutional Reinvention, which consists of the reshaping and strengthening of those institutions most prominent in the old hemispheric order, such as the Organization of American States (OAS), which has been the most prominent proponent of this theme. Such efforts seek creation of a regional institutional framework to formalize and consolidate the peaceful relations among the states of the region.

\footnotetext{
${ }^{123}$ Rojas Aravena, 1994: 176-177.
}

${ }^{124}$ David Mares, 1994: 267. 
2. Thematic Redesign, which is closely related to initiatives of institutional reinvention, is the broad-based effort to advance two hypothesis considered proven by Western, especially European, experience:

A) Civilian control of military forces needs to be strengthened.

B) The promotion of confidence - and security - building measures will, of themselves, create a complex of harmonious relationships that will prevent misunderstandings and undercut belligerent definitions of the national interest.

3. Subregional Détente, which is the enhanced bilateral and multilateral understanding that has occurred in association with progress of subregional trade integration. ${ }^{125}$

As in the other regions mentioned in the first chapter, a conceptual broadening of the definition of security is taking place in the Western Hemisphere. It is noteworthy that, at the present time, a consensus on the concept of security does not exist in the Americas, and there is also a lack of clarity regarding the type of threats that collectively affect the countries in the hemisphere. ${ }^{126}$ I believe that economic interdependence generates cooperative security. This is put into practice not only out of convenience but out of necessity between the countries in the region. This is the case because each country has a much larger stake in the security of its neighbors given that they have become increasingly interdependent. As will be shown in the next chapter, this may explain Argentine and Brazilian intervention during Paraguay's institutional crises of 1996 and 1999.

Given the present neo-liberal economic context, the competitiveness of the neoliberal market creates externalities that can only be resolved by cooperation. ${ }^{127}$ Moreover, competition in markets has led to the need for cooperation in security and

\footnotetext{
125 Downes, 1996: 3-5. My italics.

${ }^{126}$ Francisco Carrion Mena, p. 20. He cites Francisco Rojas Aravena. Look in America Latina: Alternativas y Mecanismos de Prevencion en Situaciones Vinculadas a la Soberania Territorial; Revista Paz y Seguridad en las Americas, No. 14, October, 1997, p. 15, FLACSO-Chile.

${ }^{127}$ Patrice Franko, 1996: 19.
} 
environmental policies in order to address the conflicts created by the drive toward global production. "In contrast to the use of force by the state to defend mercantile interests in the pre-capitalist era, globalized market structures will demand new forms of military cooperation to enhance security." 128 As to what the exact shape these new forms of military cooperation will take remains to be seen. Peacekeeping missions led under the banner of international organizations are apparently becoming the norm. Regional peacekeeping missions in Latin America would most likely be enacted under the banner of the OAS, and one could draw an example of this from the decisive role played by this organization during the 1996 Oviedo coup attempt in Paraguay. Even if one is to consider the idea of peacekeeping missions at the regional level as a good one, it becomes difficult to estimate just how much these will add to a nation's security over time, and at what level multi-lateral programs will detract from other missions. ${ }^{129}$ In this regard, the role of the United States as the hegemonic power in the hemisphere is tantamount, yet, there is often a clear divergence regarding the goals of cooperative security in the minds of policy makers from the United States and of those in Latin America.

Keeping in mind the three trends that were pointed out earlier, it is worth noting that new forms of hemispheric accommodation require changes in the paradigms used by decision-makers in both the United States and Latin America. ${ }^{130}$ As regards to interAmerican relations, the priorities in the US outlook toward Latin American countries that include the strengthening of democratic institutions, civilian control over the armed

\footnotetext{
${ }^{128}$ Ibid.

129 Ibid. p. 16.

${ }^{130}$ Augusto Varas, 1994: 13.
} 
forces and economic development. ${ }^{131}$ Furthermore, the issues of drug trafficking and undocumented immigration indicate that Latin American autonomy now constitutes a central reality for U.S. policy-makers. ${ }^{132}$ This means that the outlook in the United States, as a consequence of the end of the Cold War, is not on extra-hemispheric threats so much as on Latin America itself. The United States Security Strategy of the Americas document provides the following summary:

In the past, U.S. engagement in the region was episodic and unilateral with U.S. military assets applied to deal with traditional threats to security. After WWII, U.S. policy in the region tended to view local events geostrategically against the backdrop of the bipolar Cold War conflict. The direct application of U.S. military power to situations in the hemisphere often strained relations with other countries in the region.

Today, a concept of "cooperative security" is emerging, with greater emphasis on integrated approaches to shared problems. The dangers the U.S. faces today are more diverse. The line between domestic and foreign policies has blurred. Transnational phenomena like narco-trafficking and terrorism have long-term consequences for domestic and regional security. It is understood that not all security risks are military in nature and require well-coordinated approaches. But military institutions continue to play a key role in working toward solutions, and strategic planning can never discount the need for combat-ready forces. ${ }^{133}$

An enduring heritage of the United States in its foreign policy initiatives toward Latin America has been efforts by the U.S. to use its ties with Latin American institutions in order to promote agendas that have been frequently unrelated to, or even at variance with, national interests in Latin America countries. ${ }^{134}$ In this regard, organizations such as MERCOSUR are playing an increasingly important political role. Indeed, it may be a lot more difficult for the U.S. to promote agendas that are at variance with the national

\footnotetext{
${ }^{131}$ Ibid. p. 16.

${ }^{132}$ Lars Schoultz, 1994: 47.

${ }^{133}$ United States Security Strategy for the Americas, p. 2.
} 
interests in a MERCOSUR country, especially if these have a negative impact on its partners. Keeping in mind the central question of this thesis, it would appear that some relationship exists between economic integration and security cooperation in MERCOSUR due to the fact that this organization becomes relevant in the regional strategic security discourse, as I have just suggested.

\section{SECURITY IMPLICATIONS OF INTEGRATION IN THE SOUTHERN CONE}

Security cooperation as a subtext of subregional trade integration may fall victim to the surfeit of declarations and pronouncements that seems to accompany the process. With no administrative infrastructure to encourage and track progress toward stated security objectives, this process raises the specter of a hopelessly complex matrix representing little more than good intentions. ${ }^{135}$

In Latin America, the focus on economic security is an old theme that is taken up with new urgency by vulnerable democracies. ${ }^{136}$ While economic growth is not a new phenomenon in Latin America, broadly shared economic growth would be. "Thus, the link between aggregate levels of economic growth and security is tenuous and uncertain, with the former necessary but not sufficient for the latter." ${ }^{137}$ This brings us to the question of what implications neo-liberalism has for security policy in the region. A key assumption of neo-liberal theory is that the private market performs better than the state in the allocation of resources. "Its implementation is first and foremost about limiting the economic choices a state makes in the development process." ${ }^{138}$ Yet, defense is not

\footnotetext{
134 Millet, 1997: 121.

${ }^{135}$ Downes, 1996: 7.

${ }^{136}$ Stark, 1992: 3.

${ }^{137}$ Ibid.

${ }^{138}$ Franko, 1996: 14.
} 
market driven since security decision-making is the government's responsibility. In the neo-liberal context, governments are increasingly constrained in their abilities to pursue a wide range of options. With fewer available resources, the opportunity costs of making one choice versus the other increase. ${ }^{139}$ With respect to integration then, the increasing similarity among Latin American policies suggests that economic convergence is possible even amidst considerable national diversity, while on the other hand, divergent viewpoints in the field of strategic-military relations generates pressures toward national self-assertion. ${ }^{140}$ In this regard, Stark provides the following summary:

Perhaps the central paradox in the formulation of the concept of national security is that it must account for the gradual erosion of sovereignty characteristic of the post Cold-War era of interdependence. No one nation can surmount effectively problems of the environment, migratory flows, drug trafficking, or the spread of disease. The maintenance of a sovereign and stable national requires the prudent ceding of sovereignty to supranational bodies. ${ }^{141}$

At this juncture, the role played by MERCOSUR becomes instrumental. Luigi Manzetti suggests that at the political level, MERCOSUR has provided its partners with a forum for the discussion of common policies regarding nuclear proliferation, environmental protection, drug trafficking, and illegal immigration. ${ }^{142}$ This is a questionable assertion, particularly in that there is no convergence within MERCOSUR regarding labor flows that constitute immigration, environmental protection, and drug trafficking, which is an issue that has spurned varied proposals by the member states (which will be pointed out later in this chapter) but has wielded no concrete policies thus

\footnotetext{
139 Ibid.

${ }^{140}$ Varas, 1994: 11.

${ }^{141}$ Stark, p. 4. Stark defines national security as the security of the population or civil society that composes the nation.
} 
far. Regarding nuclear proliferation, one could argue that the forum for talks in this subject were provided by the Alfonsin-Sarney agreements, yet, these occurred before the inception of MERCOSUR. Manzetti is correct in asserting that MERCOSUR has played a positive role in South America by fostering political and economic cooperation among countries traditionally divided by nationalistic rivalries. ${ }^{143}$ Hence, it could be argued that the trend toward economic integration can affect threat perception in the region in a positive way. "If the MERCOSUR, and multilateral initiatives deliver promises of increased interaction, the result may be a new hierarchy of values within the individual countries." ${ }^{144}$ Economic integration could reshape perceptions of national interests, and alter evaluations of the costs and benefits of international strategic interactions. ${ }^{145}$ To reiterate, in the present neo-liberal economic context there are fewer resources available for governments, and thus the opportunity costs of making one decision over the other increases. ${ }^{146}$ In the case of the southern cone, governments are faced with the dilemma of how to spend limited resources to combat problems that are often transnational in nature, and, in the case of drug trafficking, seemingly overwhelming.

The agenda supplanting the problems of balances of power and state security, now concerns the management of human existence and include the environment, trade, drugs, hunger, technology, industrial restructuring, and migration, among others. "Within each of these issue areas the boundary between domestic and international

\footnotetext{
${ }^{142}$ Manzetti, 1992: 5.

${ }^{143}$ Ibid.

${ }^{144}$ Guedes de Costa, 1994: 140.

145 Ibid.

${ }^{146}$ Franko, 1996: 19.
} 
aspects has become increasingly blurred, tenuous and complex." ${ }^{147}$ As discussed in the previous chapter, security is undergoing a conceptual redefinition as a result of the end of the Cold War. This is a common theme that runs through the different regions that have been discussed, Latin America being no exception. Because the driving force of these new international relations is the competitiveness of economic relations, the parameters for power politics and cooperation for peace remain undefined. Given the difficulties of advancing toward a new global security regime, it may be more feasible to increase international security through the negotiation of bilateral accords and sub-regional agreements in specific thematic and functional areas. ${ }^{148}$

It is in this sense that the idea that MERCOSUR could act as a nexus between divergent viewpoints of international political and military actors, as they attempt to first attend to their own national interests, becomes worth investigating. A key question pertains to how this could be operationalized, keeping in mind MERCOSUR's institutional limitations and the fact that it is an economic organization. Before tackling this question it is necessary to discuss what the present nature of civil-military relations is and what effects these have on the practices of democracy.

\section{IN SEARCH OF A NEW ROLE FOR THE MILITARY}

In the present circumstances, it is not all clear how we might interpret what seem to be simultaneous trends in Latin America toward more democratic regimes and a decline in state capacities to maintain public security without resorting to high levels of coercion. ${ }^{149}$

\footnotetext{
${ }^{147}$ Rojas Aravena, 1994: 174.

148 Ibid. p. 172.

${ }^{149}$ Gamarra and Kincaid, 1995: 1.
} 
Gamarra and Kincaid argue that a new model of public security is emerging in Latin America in response to world systemic, international, and domestic pressures. This model has significant and unfavorable implications for the institutions and practices of democracy. ${ }^{150}$ They point to a regional pattern of state formation, as well as government responses to what are perceived as crises of public security. "One of the principal defining characteristics of this pattern is a recourse to military intervention in support of, or in place of, normal police responsibilities." ${ }^{151}$

Despite the fact that the military interventions they cite took place within legal, constitutional frameworks, and in response to the initiatives of elected civilian leaders, there is a serious threat to democratic institutions posed by these policies. ${ }^{152}$ "Both the recourse to states of exception and deployment of troops to police the streets and chase criminals pose a deterioration of citizen security, the enjoyment of basic political and civil rights." ${ }^{153}$ In the Brazilian instance, of concern are two operations known as Operation Rio I and II, which occurred in November 1994 under Itamar Franco's government, and in April 1995, with Fernando Cardoso as head of state. There were two main causes that lead to the military being called into the Brazilian favelas (shantytowns):

First, the domination of several favelas by organized criminal gangs, who were mainly involved in drug trafficking activities and commanding illegal lotteries. "The gangs increasingly were functioning as a parallel state, with local bosses (estimated to number some 300) controlling access to neighborhoods, regulating commerce, imposing curfews, and granting

\footnotetext{
${ }^{150}$ Ibid. p. 2. In their study, Gamarra and Kincaid focus on recent occurrences of the militarization of police functions in Bolivia, Brazil and Honduras. For the purposes of this work, the Brazilian case is of particular interest.

${ }^{151}$ Ibid. p. 1.

${ }^{152}$ Ibid. p. 12

${ }^{153}$ Ibid.
} 
permission for candidates to campaign for public offices. This system rested on a combination of corruption and coercion - local police and public officials were paid off for their tolerance or active involvement, while rivalries, resistance, and disobedience were settled summarily and violently. The other crucial element was a discredited police, which had come to mirror the gangs in their tendencies toward corruption and violent action. ${ }^{154}$

In Brazil, the military and civilian police are the two police systems that operate locally and that are organized at the state level. During the authoritarian regimes that lasted from 1964-1984 in Brazil, the military police forces were under centralized army control and had counter-insurgency and repressive responsibilities. Following the adoption of a new constitution in 1988 , the military police, while remaining a part of the armed forces, were placed under the authority of civilian state governors. "The civil and military police still constitute parallel organizations with overlapping functions of maintaining order, conducting investigations, serving arrest warrants, and so on."155

To synthesize, direct operations occurred beginning on November 19, 1994 and later on April 4, 1995. There were numerous human rights abuses during these operations and, while having immediate deterrent effect, soon afterwards crime increased. ${ }^{156}$ This emerging model of public security in Latin America has three noteworthy features:

1. a militarization of public security for large sectors of the population, wherein large scale disorder is repressed but crime may well flourish, and citizen security will be minimal;

\footnotetext{
${ }^{154}$ Ibid. p. 4.

${ }^{155}$ Ibid. pp. 4-5.

${ }^{156}$ Ibid. pp. 5-6. The authors point out that the typical operation involved the deployment of some 1,5002,000 troops to cordon off a particular neighborhood, attempt to serve standing arrest warrants, search for drugs and detain anyone not carrying identification. They add that controversy arose almost immediately over soldiers' abusive treatment of those they detained, and over the fact of detention itself, since carrying identification is not required under Brazilian law.
} 
2. a simultaneous informalization of some public security functions, whether provided in the form of paramilitary neighborhood groups, ... or the "parallel state" of shantytown criminal organizations, ...; and

3. a privatization of public security for those who can afford to pay for it, as a commodity to be purchased. ${ }^{157}$

There are two causal explanations for the emergence of this model. One is Guillermo O'Donnell's "crisis of the state", which is the contemporary interaction of neo-liberal economic policies and the specific historical formations of state and political systems. From this perspective, the shrinking of the state undermines state capacities for extending the effectiveness of the rule of law across both territory and social order in an equitable manner. ${ }^{158}$ The second explanatory factor is the transnational economy of illegal drugs, which is seen as a perverse form of integration into the world economy for national and local economies and social actors. "In sum, the dynamics of illegal drug trafficking interact with those of the weakened Latin American state to fuel the contemporary crisis of public security. ${ }^{, 159}$

\footnotetext{
${ }^{157}$ Ibid. p. 13. In relation to the third feature of this proposed model, the La Nacion article La funcion policial no es delegable, dated August 2, 1999, argues against the recent Buenos Aires law (Provincial Law \# 12.297) that gives private security officers policing powers. This law states that officers employed with private security agencies in the Buenos Aires territory may guard not only their specific work place, but its immediate surroundings as well. Moreover, in those immediate surroundings, an officer may react not only to delinquent actions but those to those persons that he may perceive as acting suspicious with the same coercive authority that a police officer is entitled to utilizing. They are entitled to use weapons for intimidation purposes as well as for legitimate self-defense. The goal of provincial political authorities is to integrate, through cooperation, private and public security forces to prevent crime. The author wonders whether all possible measures have been taken to improve the public police forces so that they may better execute their mission, and whether private security officers are properly prepared to partake some of the roles that society has assigned to police officers. The author concludes that public security should not be delegated and is the sole function of the state, and argues that assigning civilians police authority is unacceptable. The author suggests that such an occurrence smacks of vigilantism.

${ }^{158}$ Ibid.

159 Ibid.
} 
Policies oriented to demilitarizing efforts to cope with the transnational drug economy should be considered so as to reduce the levels of violence associated with it. ${ }^{160}$ This may not be a very viable alternative, however, given the pressure that the U.S. puts on Latin American countries to enlist their militaries in the war against drugs. This strategy is regarded as a recipe for disaster by every government in the region. ${ }^{161}$ In a similar vein, Richard Millet argues that military involvement in operations against narcotics traffickers and other organized criminal activity has become cause for mounting concern. "Questions have also arisen over what role, if any, the military should play in defending the environment, in dealing with migration, and in developing the economy."162

As pertaining to Argentina, the Law of Interior Defense outlines that the maintenance of interior security implicates the human and material employment of all police and national security forces. ${ }^{163}$ National security forces, of course, include those that are military in nature. In the same document it is further specified under which circumstances security forces, outside of the norms that rule the federal jurisdiction, may be strictly used to fulfill the following maneuvers:

1. When the collective life, liberty and patrimony of the habitants of a determined region are endangered.

2. When the constitutional rights and guarantees of the institutions of the representative system, republican and federal, are seriously threatened.

3. In situations of disaster according to the terms that dictate civil defense. ${ }^{164}$

\footnotetext{
${ }^{160}$ Ibid. p. 14.

${ }^{161}$ New York Times, 6-2-99. Latin America's Armies Are Down, But Not Out.

${ }^{162}$ Millet, 1997: 122

${ }^{163}$ Ley De Seguridad Interior, Law 24.059, Title I, Article 3 (1988).

${ }^{164}$ Ibid. Title IV, Article 23.
} 
Apparently, under certain social circumstances, the Argentine military is, within the bounds of legality, allowed to intervene and partake police functions. Furthermore, and in the context of the still undefined role(s) that the militaries of the Southern Cone region should play, the debate regarding some type of MERCOSUR defense doctrine is relevant. The polemical project for the creation of a common security system for MERCOSUR was inspired by an increase in the number of social conflicts, as well as increasing levels of transit and the consumption of drugs in Argentina and Brazil. ${ }^{165}$ The Argentine Ministry of Defense stated that such a "Sistema de Seguridad Comun" (Common Security System) of the respective armed forces would include a mechanism to prevent social, cultural, and/or political processes of destabilization in the member states. "The idea is that if there is an agreement between Argentina and Brazil, then a consensus could be attempted with Paraguay and Uruguay so that MERCOSUR may incorporate a military agreement to its commercial and economic pacts."166 The document, published by the Ministry of Defense, faced overwhelming opposition and was rejected by Congress. Yet, such an attempt may be seen as a step from cooperative security to the common security of Argentina and Brazil. Interestingly, this particular proposal was made by the Ministry of Defense, and not by the Ministry of Exterior Affairs. Simply put, the military, in seeking to extend its role, is apparently attempting to increase its political power and autonomy. It is telling that the main opposition parties, Frente Solidário del País (FREPASO) and the Radical Party (UCR) were unanimous in their stance against the project that Defense Minister Jorge Dominguez proposed. The Radical senator Juan Pablo Baylac stated that at the internal level it is a judicial aberration, and

${ }^{165}$ Clarin, 7-28-97. Conflictos Comunes A Ambos Paises. 
that at the external level it would implicate the renunciation of a posture of autonomous national defense and sovereignty. ${ }^{167}$

The idea of establishing a bi-national army such as has been experimented with the militaries of France and Germany is one thing, but to delegate police authority to the armed forces, especially ones composed of the members of two different countries is an entirely different dimension. ${ }^{168}$ One could only imagine the negative repercussions from Argentine military officers dealing with crime in the Brazilian favelas, for example. The idea that has been proposed by the U.S. Southern Command of utilizing the military to battle diverse problems such as drugs, economic marginality, so on, is not very popular among most Latin American countries. ${ }^{169}$

Argentine Counselor Marcelo Cima argues in his thesis that even though the definition of security has been widened, this does not mean that the military should play a major role in battling non-traditional security concerns. ${ }^{170}$ This argument stems from the fact that high-ranking Argentine military officers have on several occasions visited the U.S. Southern Command without the consent and/or knowledge of the Argentine Ministry of Foreign Affairs. He contends first that Argentina must determine what its institutional position is in the face of an altered bilateral relationship with the United States. The second contention is that the greatest contribution that the United States can make should be in helping Latin Americans recognize the necessity of engaging informed

\footnotetext{
${ }^{166}$ Ibid.

${ }^{167}$ Ibid. 7-29-97.

${ }^{168}$ Clarin. Oscar Cardoso, El Projecto De Seguridad, 7-29-97

${ }^{169}$ Ibid.

${ }^{170}$ Cima, 1998.
} 
civilians in all aspects of security policies. ${ }^{171}$ "Promoting dialogue between civilians and the military on every level, both national and international, can represent, in and of itself, not only a significant break from past traditions but also an important step toward consolidating effective civilian control."172 Cima's main argument is that the present direct relation between the Ministry of Defense or the Commanders of the Argentine Armed Forces with U.S. Southern Command to resolve issues that are pertinent to Argentine interests is unacceptable since these contain a political content that goes beyond what is strictly military. ${ }^{173}$ Tied into this is a current debate in Argentina in which on the one hand, there is a consensus in hemispheric meetings that there are new security threats and thus new military roles, while on the other, there are in existence national legislations that are much more restrictive in this respect. ${ }^{174}$ Hence, Millet may be correct in stating that in Latin America, the armed forces will do whatever they can to maintain their autonomy, privileges, and power. ${ }^{175}$ Civilian-military issues attain further relevance in the context of MERCOSUR when we look at the Paraguayan case and the social and political events that have taken place there since 1996, beginning with the Oviedo coup attempt and its aftermath, which led to a very serious institutional crisis that culminated with worrying results in the first half of 1999 . It is to these events that the next chapter will turn, and what mediating role the MERCOSUR countries played to stabilize the political situation in Paraguay in order to maintain democracy.

\footnotetext{
${ }^{171}$ Ibid. pp. 75-76. Look also in Millet, 1997: 129.

${ }^{172}$ Millet, 1997: 129. See also in Cima, 1998: 76.

${ }^{173}$ Cima, p. 79.

174 Ibid. p. 82.

${ }^{175}$ Millet, 1995: 297.
} 


\section{CHAPTER 3}

The strong national and international defense of Paraguayan democracy against the threat of General Oviedo's attempted military coup in April 1996, while highlighting the delicate nature of the transition, also reflected the strength of support for democracy in Paraguay. ${ }^{176}$

Consistent with the central question of this work, which asks if economic integration is conducive to security cooperation, as a case study I look at the Paraguayan experience both as a country undergoing a transition to democracy, and as member of MERCOSUR. Paraguay's membership to this economic organization is conditional on its maintenance of democracy. The so-called democratic clause of the MERCOSUR has effectively served as a link between the economic nature of this organization and the active intervention of Paraguay's partners in its internal security. In light of the trends that have already been discussed in this work, I believe that this case study will provide the necessary evidence with respect to the validity of the proposed hypothesis.

The first section of this chapter will examine the transition from the Stroessner dictatorship to democracy. In doing so, it will be shown that certain characteristics of the Stroessner era remain intact, bringing into question the genuineness of this democratic transition. This is important to this work because these persistent traits have hindered the Paraguayan democratic process. As a result, institutional crises brought on by this fledging democracy has brought in several international actors such as the OAS, the US and MERCOSUR into the scene.

\footnotetext{
${ }^{176}$ Peter Lambert, 1997b: 210-11.
} 
With respect the Stroessner legacy, political and economic power held by traditional civilian and military elites remains entrenched and are fueled in great part by corrupt activities. The armed forces still maintain considerable influence not only within the military sphere, but in non-military issues as well. This may not bode well for efforts to further the democratization process in this country. Moreover, the arrival of a new military strongman in General Lino Oviedo signals all too well that the structure of Paraguayan politics de facto has not been completely altered. ${ }^{177}$

The second part of this chapter will analyze the events that led to Oviedo's attempted coup and the international opposition to it. Particularly, the role of the US, the OAS and MERCOSUR will be analyzed. The final section will discuss the Cubas presidency and the ensuing discord with Congress and the Judiciary over Oviedo's tenyear sentence for attempting the coup. Cubas pardoned Oviedo of that sentence and Congress began the process to impeach him as a result. The March 1999 murder of Luis Maria Argaña and Oviedo's possible involvement culminated in Cubas's resignation and his departure to Brasilia where he was granted political asylum. Oviedo, in turn, was granted political asylum in Argentina. The active involvement of Paraguay's MERCOSUR partners in this country's domestic political affairs points not only to their key mediating role but has become a serious point of contention, particularly in Argentine-Paraguayan and Paraguayan- Uruguayan relations. These points of contention will be discussed in the third section of this chapter.

${ }^{177}$ Carlos Martini and Carlos Maria Lezcano, 1997: 65. 


\section{THE PARAGUAYAN TRANSITION TO DEMOCRACY}

\section{THE STROESSNER LEGACY}

Paraguay's historical prelude to Stronism is the Chaco War against Bolivia, which took place between 1932 and 1935. The war is significant because it expanded the role and prestige of the military and resulted in the politicization of the middle class. ${ }^{178} \mathrm{~A}$ serious political crisis ensued and resulted in Paraguay's first military dictator, General Higino Morinigo. He took power in 1940, but was overthrown as a result of the Paraguayan Civil War of 1947. Colorado Party loyalists won the Civil War, but could not control their internal divisions. The Colorados eventually allied with the military, and General Alfredo Stroessner subsequently took power in a 1954 coup. ${ }^{179}$

Interestingly, Stronism became exclusionary on the basis of party affiliation, and was not a class-based exclusionary regime like the bureaucratic-authoritarian regimes of other Southern Cone countries in the 1970s, for instance. "The unusual characteristic of the Stroessner dictatorship was that it was neither personalistic, military, nor one-party rule, but rather, a combination of the three. The military never ruled but it guaranteed the coercive power of the regime and was wholly partisanized."180

\footnotetext{
${ }^{178}$ Nancy Powers, 1992: 3. In her working paper based on a 1992 conference involving the Paraguayan transition to democracy she cites the presentations of several authors. She points out Diego Abente's argument that the aftermath of the Chaco War resulted in the dominance of the fascist-influenced Colorado Party, a divided Liberal Party, and increased public disenchantment with a government that could win a war but could not bring about economic development. Ibid.

${ }^{179}$ Ibid.

${ }^{180}$ Ibid. Powers adds that the Colorado Party was used to mobilize support down to the precinct level. She further points out that this triad of party-army-state was so conjoined that one of the keys to a successful transition is the emergence of Colorado Party and military leaders who will perceive and accept their institutions as distinct from the state.
} 
Stroessner built a type of patrimonialism, which in Weberian terminology is

known as sultanism. To Weber:

Patrimonialism and, in the extreme case, sultanism tend to arise whenever traditional domination develops an administration and a military force which are purely personal instruments of the master [ruler]... Where domination... operates primarily on the basis of discretion, it will be called sultanism... ${ }^{181}$

The power of the Stronato was based upon the consolidation of the tripartite structure made up of the armed forces, the government and the Colorado Party. He was the head of each institution of this "sultanistic" institutional structure. ${ }^{182}$ All three components played different roles in repression, political control and in weakening civil society. ${ }^{183}$ Corruption and contraband represented key economic bases during the Stronato. "Highranking military officers, politicians and party members enjoyed access to lucrative commercial ventures, ranging from state monopolies, public contracts to contraband and drugs, prostitution and the black market."184

\footnotetext{
${ }^{181}$ Quoted in Linz and Stepan, 1996: 51. Powers further points out that "sultanistic" regimes involve attention to legal forms (Stroessner held and fraudulently won eight presidential elections), combined with corruption, arbitrary decisions, repressive violence, imposition of personal rule, and the accumulation of wealth of ruler and cronies. Powers, 1992:3-4. Andrew Nickson adds that Stroessner's blend of sultanism consisted of a highly centralized form of rule, in which reciprocal ties of material support and obligation, rather than tradition or charisma (as under patrionalism) provided the basis for personal loyalty to the ruler. Nickson, 1997a: 24.

${ }^{182}$ Stroessner was president, commander-in-chief and senior officer of the military, as well as the honorary president of the Colorado Party. My quotation.

${ }^{183}$ Lambert, 1997a: 3-4.

${ }^{184}$ Ibid. p. 11. With regards the military, the ideological underpinning of this institution was the National Security Doctrine (NSD), a Cold War import from the US. Lambert points out that "according to the NSD, the enemy was not external but rather internal, within opposition organisations. Supposedly influenced and organized by international communism, these groups manifested themselves in any anti-government movement or organisation. Although internal security against subversion became the priority of the military, the absence of any serious communist or even left-wing challenge to the regime after the 1960s indicates that the NSD was adopted for other motives: it justified large-scale investment in the security forces, it facilitated economic support from the US and above all it justified repression against real or perceived opposition. Moreover, it gave legitimacy to the authoritarian nature of the regime." Ibid, p.8.
} 
Regarding the military, corruption was key for Stroessner to ensure support for the regime from that institution. ${ }^{185}$ This was facilitated by Stroessner's decree that allowed officials who were on active duty to participate in private business activities. ${ }^{186}$ He effectively permitted the military to take almost full control over the infrastructure and logistics of Paraguay's massive black market smuggling networks. ${ }^{187}$ Stroessner used the benefits of corruption to defuse potential intra-elite conflict, while contraband served not only the interests of elites but imbued society as a whole by guaranteeing prices lower than those on international markets. ${ }^{188}$ This created an illusion of material development, especially among the middle and mid-lower classes. Moreover, the informal sector, which was based on contraband and corruption, created a convergence of interests between elites and masses in the maintenance of the status quo. ${ }^{189}$

The façade of limited multi-party democracy and legality were key regarding foreign support for the regime. This enabled Stroessner to escape the international scrutiny that presented the other Southern Cone dictatorships. In the Cold War context, Stroessner attained US support through his anti-communism and "his advocacy of 'Paraguayan Stronista democracy'."190 Also, during the Stroessner dictatorship,

\footnotetext{
${ }^{185}$ Andrew Nickson, 1997a: 25. Nickson cites a 1965 interview where Stroessner alluded to "military control of the contraband trade as 'the price of peace' (el precio de paz), suggesting that military discontent was lessened by the prospect of rich pickings to be gained through officially sanctioned illicit activities." Ibid.

${ }^{186}$ Ibid. Nickson adds that the fact that many officers dedicated themselves almost full-time to private business and utilized equipment belonging to the armed forces for personal purposes contributed to a lack of professionalism in the armed forces. Ibid. pp 25-6.

${ }^{187}$ Barreto, 1996: 14. [Look up this source] Andrew Nickson states that among the range of illicit activities that the military hierarchy was involved in, the three most important were contraband, narcotics trafficking and arms trafficking. Nickson, 1997a: 26.

${ }^{188}$ Lambert, 1997a: 11.

${ }^{189}$ Ibid. Lambert adds that this consensus among the majority of the population became a central component of Stroessner's control over civil society and the longevity of the Stronato.

${ }^{190}$ Ibid. p. 13. Lambert points out that although democracy and anti-communism were not deep-rooted beliefs of Stroessner, they made sound economic sense during the Cold War.
} 
Paraguay tried to overcome its traditional economic and political dependence on Argentina by strengthening relations with Brazil. This culminated in the signing of the Itaípu Treaty on 26 April 1973, which initiated the construction of the gigantic Itaípu hydroelectric project. This plant is the world's largest and was built in a joint venture with Brazil, who provided the technology and guaranteed Paraguay's construction debt. Construction took place between 1974 and 1981, and the massive capital inflows from this project provided impressive gains in levels of employment, income, and spending. "This seven-year boom is responsible for Stroessner's reputation of bringing growth and prosperity to the country, and it enabled him, for a time, to legitimate his regime."191

The 1980s, however, saw the end of international support for the Stronato, particularly from the United States. Stroessner's refusal to liberalize despite US pressure, and the alleged involvement of senior officials in the international drug trade, resulted in the straining of relations with its previous ally. Lambert offers:

By the late 1980s, growing political instability and the intransigence of Stroessner led the US to favor more drastic measures to restore stability and create a democratic opening in the country. The stronato also found itself increasingly bereft of ideological allies in the region. Isolation was heightened by the increasing economic integration of the Southern Cone countries of Brazil, Argentina and Uruguay. Exclusion from the benefits of regional economic integration, combined with the restrictive economic policies of the Stroessner government, gave an impetus to powerful economic sectors favoring democratization. ${ }^{192}$

Despite the fact that Paraguay was finding itself increasingly isolated by its regional neighbors and the US, it was a crisis within the regime that triggered military

191 Powers, 1992: 5.

${ }^{192}$ Lambert, 1997a: 17. 
rebellion and ultimately resulted in the fall of Stroessner. ${ }^{193}$ By the mid- 1980 s, The Colorado Party had been divided into two camps: the militantes and the tradicionalistas. The militante faction led Stroessner to believe that they would be able to maintain his political model through a succession process involving his son, Air Force colonel Gustavo Stroessner. ${ }^{194}$ "To achieve this they had to subordinate the Colorado Party and the armed forces to their plan of continuing Strossismo after Stroessner."195

"In 1987, internal factionalism openly broke out for the time since 1959. At issue was control of the pebendary system as well as the succession to Stroessner."196 Following the internal party elections of May 1987, the militantes gained control of the Colorado Party, and through that the public sector. The militantes failed, however, in the next step towards achieving their objective in Stroessner's succession. They believed that Rodríguez lacked the sufficient backing to rise up against Stroessner, and thus attempted to remove Rodríguez from his position as commander of the First Army Corps. This turned out to be a serious miscalculation as commanders loyal to Rodríguez began to organize themselves against militante power. ${ }^{197}$ All of this culminated in a Rodríguez-led

\footnotetext{
193 Ibid.

${ }^{194}$ Martini and Lezcano, 1997: 65-66.
}

${ }^{195}$ Ibid. p. 66 . They point out that there were two obstacles to achieving this: First, the tradicionalista faction of the Colorado Party "were business partners and in some cases even relatives of high-ranking military leaders. Second, the need to create a new chain of military loyalties subordinate to Stroessner in preparation for the succession required the exclusion of the commander of the powerful First Army corps, General Andres Rodriguez, as well as a large sector of his team of high-ranking officers." Ibid. Interestingly, Rodríguez had been Stroessner's hand picked successor before this turn of events. ${ }^{196}$ Marcial A. Riquelme and Jorge G. Riquelme, 1997: 50. They state that in 1959, the Colorado Party split up when Stroessner expelled a faction of the party leadership that was interested in democratizing the country. "This group later formed the Movimiento Popular Colorado (MOPOCO) in exile." Ibid. p. 64.

${ }^{197}$ Martini and Lezcano, 1997: 66. 
1989 putsch that overthrew Stroessner. ${ }^{198}$ Interestingly, it was a little known lieutenantcolonel who arrested Stroessner: Lino Oviedo.

\section{THE RODRIGUEZ REGIME AND THE RISE OF LINO OVIEDO}

A democratic transition is complete when sufficient agreement has been reached about political procedures to produce an elected government, when a government comes to power that is the direct result of a free and popular vote, when this government de facto has the authority to generate new policies, and when the executive, legislative and judicial power generated by the new democracy does not have to share power with other bodies de jure. ${ }^{199}$

The new Paraguayan president, General Andrés Rodríguez, had been a Stroessner supporter who had amassed a great fortune from corruption during the Stroessner regime. $\mathrm{He}$ "had come to occupy a pivotal role in the armed forces' involvement in contraband, narcotics trafficking and money laundering. ${ }^{, 200}$ In light of this, Rodríguez attempted to counter his negative image in the international media and cripple political opposition to the coup from within the Colorado Party by arresting the leadership of the militante faction. They were subsequently charged on counts of corruption and human rights

${ }^{198}$ Riquelme and Riquelme, 1997: 50. They point out that the tradicionalistas supported the military coup and became the civilian power base of the Rodriguez government. "In the aftermath of the coup, the most prominent militantes were removed from power and a few were jailed for corruption. However, the vast majority of the militantes re-entered the political fold in the 1992 internal Colorado Party elections.

199 Juan J. Linz and Alfred Stepan, 1996: 3. Their italics.

${ }^{200}$ Nickson, 1997a: 31. Nickson shows that despite the fact that Paraguay had been utilized as an entrepot in the international narcotics regime since the early days of the Stroessner regime, it was the Ricord Affair in 1971-2 that initially drew international attention to the extent of heroin smuggling from Europe to the US through Paraguay (cites Adams, 1973: 201-40; Clark and Horrock, 1975: 3-22). Nickson, 1997a: $26-7$.

Gen. Rodríguez was among those high-ranking military officials who were accused by the US government of involvement in the traffic. Gen. Rodriguez, at the time second in command of the armed forces, was put in the US Drug Enforcement Agency's blacklist and was prohibited to enter the US until 1988. In that year, a rapprochement took place between the US government and Rodriguez as a response to the rise of the extremist militante faction of the Colorado Party. "The US government quietly dropped its accusations of narcotics trafficking against Rodríguez and instead directed them against Stroessner." Ibid. p. 27. 
violations. ${ }^{201}$ Stroessner and his son Gustavo, on the other hand, were allowed to leave for exile to Brazil. ${ }^{202}$

On February 3, 1989 (the morning after the coup), Rodríguez established the five objectives of the putsch:

1. The reunification of the Colorado Party in government.

2. The restoration of the dignity of the armed forces.

3. The beginning of a process of democratization

4. Respect for human rights

5. Defense of the Catholic faith. ${ }^{203}$

The aim of the first two objectives was the restoration of the Colorado Party-Armed Forces alliance in government. The last three objectives were in response to the social and political opposition, as well as to the international community. ${ }^{204}$ Regarding the effects of the putsch, Martini and Lezcano argue that:

The 1989 putsch did not break the link between the armed forces and the Colorado Party. But it did alter the political context within which this link operated. The keys of the Rodriguez government were, domestically, to consolidate the power of the civilian-military elite and, internationally, to strengthen its own legitimacy, given its origins as a military putsch. ${ }^{205}$

In an apparent effort to strengthen his legitimacy, Rodriguez called for democratic elections to be held on May 1989. He stated that he would run in these elections in order to finish Stroessner's final elected term (which ran through 1993), and promised that he would not run again in 1993. Rodríguez proclaimed that the "main purpose of the election was to elect a representative Congress to draft a new electoral law, then call a constitutional convention, thereby instituting a structure allowing fully free and fair

\footnotetext{
201 lbid.

202 Ibid. p. 32.

${ }^{203}$ Martini and Lezcano, 1997: 67.

${ }^{204}$ Ibid.

${ }^{205}$ Ibid. p. 69.
} 
elections in 1993."206 Rodríguez then reduced the military's internal security role, ended a ban on opposition political parties, ended newspaper censorship, freed political prisoners, and reached an agreement with the Catholic Church. ${ }^{207}$ These initial democratic openings and his party's vast electoral support, coupled with Rodríguez's popularity for leading Stroessner's overthrow, catapulted him into the presidency on May 1989 with $74.2 \%$ of the popular vote. ${ }^{208}$

Foreign policy was an area that had been relegated a secondary role during the final Stroessner years, but attained a newfound significance in Paraguayan politics after 1989, beginning with the Rodríguez administration. Fernando Masi points to three reasons of why this is the case:

1. The Rodríguez government sought international support as a form of political legitimacy.

2. In response to the end of the Cold War, the US abandoned its traditional policy of support for authoritarian regimes in the region and developed a policy of support for democratic regimes.

3. The global move towards regional economic integration in the European Community and the countries of the Pacific Basin gave a new urgency to the question of foreign policy. ${ }^{209}$

Foreign relations came to play an important role in the Paraguayan transition to democracy. As an example, Fernando Masi argues that the decision to join MERCOSUR was basically a political one, and was not preceded by any serious study of the economic advantages or disadvantages for Paraguay. Instead, it helped launch Rodriguez's policy

\footnotetext{
${ }^{206}$ Collier, 1998: 8 .

${ }^{207}$ Freedom House, 1989: 36-38.

${ }^{208}$ Riquelme and Riquelme, 1997: 53. They state that "Gen. Rodríguez called elections for 1 May 1989 on the grounds that this complied with the constitutional requirement that elections should be held within three months of the dissolution of a government. His reasoning was criticised as spurious because the constitution had already been violated by the military coup. The real reason behind the hasty call for elections appeared to be the need to gain international legitimacy for his de facto government." Ibid. pp. 52-3. Their italics.

${ }^{209}$ Masi, 1997: 181.
} 
of presidentialist diplomacy and to promote a new international image for the country. ${ }^{210}$ Strategic factors also played an important part in the decision to join MERCOSUR since a refusal to participate would have meant that the land-locked country would be left with little room to maneuver stuck between two economic blocs: the Andean Community and MERCOSUR. "The Rodríguez government gradually adopted a more favorable policy towards regional integration as it realized that MERCOSUR opened up new opportunities for economic development that could redress Paraguay's lack of international competitiveness. 211

On the home front, divisions within the Colorado Party continued to be a problem. During the 1991 municipal elections, the Colorado Party lost more than 40 municipalities out of a nationwide total of 200 due to the fact that it ran as a divided party, often standing a number of candidates against each other. ${ }^{212}$ These election results sent a clear message to the military hierarchy: "a divided Colorado Party ran the risk of being defeated in the 1993 presidential elections." ${ }^{213}$ If this were to occur, the military's involvement in illegal business practices could be exposed to unwelcome public scrutiny. As a result, efforts to professionalize the military were reduced as Rodriguez, in a July 1991 statement, called for a return to the granite-like unity (unidad granítica, which was a common expression during the Stroessner era) of the Colorado Party. ${ }^{214}$ Among those with Rodríguez when he made this statement was a then little known General, Lino Oviedo. With respect to Oviedo's rise, Martini and Lezcano offer:

\footnotetext{
${ }^{210}$ Ibid, pp. 178-9.

${ }^{211}$ Ibid. p. 179.

${ }^{212}$ Martini and Lezcano, 1997: 69.

${ }^{213}$ Ibid. pp. 69-70.

${ }^{214}$ Ibid. p. 70. At the time the Colorado Party was divided into six different factions. Ibid.
} 
The July 1991 statement also heralded the formal entry into political arena of General Lino Oviedo. From a position of obscurity under Stroessner, the rise of Oviedo had been meteoric. Within a year of the putsch, in which he had played an active role, Oviedo was named commander of the First Calvary Division, occupying the thirtieth place in the rankings of brigade generals. He then proceeded to clear the path to his own advancement within the armed forces. ${ }^{215}$

General Oviedo supported the candidacy of Juan Carlos Wasmosy in the internal Colorado elections of December 1992, which turned out to be defining in Wasmosy attaining the Colorado nomination. In a late April speech to the Ministry of the Interior, Oviedo stated that the armed forces and the Colorado Party would rule Paraguay forever and ever. Oviedo was becoming a very powerful political figure and openly campaigned for the Colorado Party and its candidate, Wasmosy, for the 1993 presidential elections. "This was a flagrant violation of the 1992 Constitution which expressly prohibited political activity by members of the armed forces."216

During the transition there were initial hopes of dismantling the civil-military pact, but when the risk of a 1993 electoral defeat became a reality, this civil-military elite resorted once again to utilizing the state apparatus in order to ensure a Colorado victory. ${ }^{217}$ As a point in fact, Juan Carlos Wasmosy was picked as the Colorado Party presidential candidate particularly because he was a civilian figure able to unite the party with the military, and effectively maintain the civilian-military pact. Ironically, the democratic transition produced a new military strongman in politics with obvious future presidential aspirations in Lino Oviedo. Martini and Lezcano argue that Oviedo is the product of a civil-military relationship that has been cemented over a half century and

215 Ibid.

216 Ibid. 
still remains in place. "Until the contradiction of the existence of a civilian-military pact within the democratic state is resolved, there will be no shortage of other military figures prepared to continue the long Paraguayan tradition of generals holding political power."218 This is an important point to keep in mind since it cuts across several themes that are treated in this thesis. One of these is civil-military relations within the context of democratization in the region. Of the Southern Cone countries, Paraguay has the most politicized military, this being a lasting legacy of the Stroessner era. The caudillo spirit, if you may, runs deep in Paraguayan political culture and this is highlighted in the number of factions ( 6 at one point) within the Colorado Party. Within the same party, there are arch-enemies such as Oviedo and Argaña as we will see later. This emphasis on personalism, as opposed to institutionalism, coupled with a politicized military runs counter to democratic procedures and respect for constitutional restraint, allowing ambitious generals like Oviedo to amass a lot of support and constantly test the democratic process. The MERCOSUR organization, not exclusively since other international actors play important roles, comes into play when institutional crises bring this country to the brink of a military take-over. More than economic interests, the bloc's international standing is threatened by the internal security problems of this country.

\section{THE 1996 COUP AND MERCOSUR}

\section{THE WASMOSY-OVIEDO NEXUS}

Military interference in the presidential elections of May 1993 was overt, both in the choice of the party candidate and in the election campaign

${ }^{217}$ Ibid. p. 71

${ }^{218}$ Ibid. 
itself. This strengthened the argument that effective enforcement of the constitutional prohibition on such military involvement in politics could only be achieved through congressional control over military appointments. ${ }^{219}$

Wasmosy's rise to power as president, while ensuring the control of Paraguay's civil-military elite on the economic and political destiny of the country, did little to sustain the power struggle within the elite. His victory had been made possible by the support of Gen. Oviedo and Blas Riquelme, a businessman and important broker within the Colorado Party. ${ }^{220}$ These two men had reluctantly supported Wasmosy because they were afraid that Luis María Argaña might take office. "Wasmosy was thus beholden to the civil-military interests that had brought him to power."221

There were evident cracks within the alliance that had brought Wasmosy to power only a few months after he was elected president. Faced with an opposition majority in the new Congress and waning support within his own party (Foreign Minister Diógenes Martínez and Colorado Party president Blas Riquelme resigned their government posts in late 1993 and early 1994, respectively), Wasmosy signed a governability pact with the PLRA (the Liberal Party), the Febrerista and Christian Democrat parties on January

\footnotetext{
219 Nickson, 1997a: 39-40.

${ }^{220}$ Nickson, 1997b: 186.

${ }^{221}$ Ibid. Regarding Luis María Argaña (former head of the Supreme Court under the Stroessner regime and former Minister of Foreign Relations under the Rodriguez administration) Marcial and Jorge Riquelme point out that although a previous supporter of Rodriguez, "Argaña's repeated challenges to the authority of Rodriguez, together with his campaign to de-militarise the Colorado Party (but not 'de-partisanise' the military) made his candidacy unacceptable, both to Rodriguez and to the armed forces." Riquelme and Riquelme, 1997: 58. They also point out that Wasmosy (a civil engineer, businessman, and prominent figure within the powerful land-owners association, Asociación Rural del Paraguay, who had never held a party post and as a result had little influence within the party) was chosen by the military and Rodriguez to be the Colorado presidential candidate for two reasons. "First, he represented the continuation of the alliance between the armed forces, dominant economic interests and political elites within the Colorado Party who had constituted the base of support for the Stroessner regime. Second, the choice of a 'business' candidate was necessary to counter the appeal to the private sector of businessman Guillermo Caballero Vargas, who was standing for the [Encuentro Nacional] EN." Riquelme and Riquelme, 1997: 57-8.
} 
1994..$^{222}$ Even though the governability pact enabled the passage of legislation that originated from the executive, such as measures for economic liberalization, it did not do much as regards the necessary fundamental structural reforms to strengthen the democratization process. ${ }^{223}$

Wasmosy was initially opposed to reform of the armed forces. The main point of contention was the issue of the entrenched privileges of the armed forces that were inherited from the Stroessner era, and their repeated political interventions to defend them. Congress displayed tremendous determination on this issue, and little progress was made. Congress also expressed concerns over the quick rise of Oviedo (only three days after Wasmosy's inauguration Oviedo was promoted to the head of the army). To the opposition majority in Congress, the rise of Oviedo demonstrated that the military still constituted a significant threat to the entire democratization process. "Consequently, the issue of political interference by the military became the major source of conflict between Wasmosy and Congress."224 Another key area of conflict between Congress and the executive became the issue of party affiliation for serving members of the armed forces. During the Stroessner regime, Colorado Party affiliation was a precondition for joining the officer corps, but the 1992 Constitution barred all party affiliation in the future. The

\footnotetext{
${ }^{222}$ Ibid. p. 187. Nickson states that the pact promised prior consultations with these parties regarding proposed government legislation. The other major opposition party, the EN, decided not to be a signatory. The new opposition alliance in Congress consisted of the EN, dissident Colorados of the MRC (the Movimiento de Reconciliación Colorado were a faction led by Argaña who were spiteful of the fradulent manner in which Wasmosy had obtained the party's presidential nomination with military support despite him having been defeated by Argaña in the party's primaries) and a minority faction of the PLRA. Ibid. pp. 186-7.

${ }^{223}$ Ibid. pp. 187-8.

${ }^{224}$ Ibid. pp. 189-190. Nickson adds that "congressional opposition to a law hurriedly passed by the outgoing Congress in July 1993 at the insistence of then President Rodríguez became the initial focus of this conflict. This law had created a new post of Commander of the Military Forces between the president and the head of the armed forces and congress feared that the new post-holder, rather than the president,
} 
1992 Constitution did not, however, rule on existing party affiliations. Congress rectified this when on May 1994 it ratified Law 261, which suspended party affiliation for serving members of the police and the armed forces. Wasmosy found himself with no choice but to promulgate this law. ${ }^{225}$ Lino Oviedo responded to this congressional decision by campaigning against it in the armed forces and the Colorado Party. He continued attending Colorado Party rallies and making public statements on political issues, despite staunch opposition to this from Congress. "For many he now personified the threat posed by the military to the democratisation process. ${ }^{, 226}$

In late 1994 Wasmosy started distancing himself from Oviedo for fear that the latter's growing ascendancy and his association with him was beginning to tarnish his own democratic credentials. ${ }^{227}$ In February 1995, Wasmosy promoted two generals ahead of Oviedo in order to quell the latter's meteoric rise to power. A further sign of the distrust between Oviedo and Wasmosy came on May of the same year when Wasmosy and the opposition signed a pact in order to de-politicize the armed forces. Oviedo reacted by staging a major public relations exercise in which his flag-waving supporters called for him to become president. ${ }^{228}$

In late August 1995, Congress passed a motion ordering Oviedo's dismissal on the grounds that he had disobeyed the constitutional ban on party involvement by serving

would exercise control over military appointments. Wasmosy vetoed its decision but on 9 December Congress reasserted its original decision by rejecting the presidential veto. "Ibid. p. 190.

225 Ibid. p. 190.

${ }^{226}$ Ibid.

${ }^{227}$ Ibid. Nickson adds that this rift resulted in a serious military crisis on 18 December 1994 . While Wasmosy was attending a MERCOSUR summit meeting in Brazil, Oviedo unilaterally relieved General Carlos Ayala of his command of the third infantry division, to transfer him to the Chaco garrison. Ayala refused the order and the air force, which remained loyal to the president, put on a display of strength that finally defused the situation. Upon his return, Wasmosy rescinded the order, and attributed the mix-up to a misunderstanding with Oviedo. Ibid. pp. 190-1. 
members of the armed forces. It was decided by the judge in charge of the case that there was insufficient evidence to support these charges and the suit was thrown out. Congress persisted, however, with the attorney general appealing against the ruling, as the congressional investigating committee took the case. The committee summoned Oviedo to answer the charges in person, but he refused to show up citing that he needed permission from Wasmosy to do so. As a result of its worsening rift with Oviedo, Congress adopted a more conciliatory stance toward Wasmosy. In November, the senate dropped a bill, designed specifically to stop Oviedo's presidential ambitions, which called for the extension of the minimum period that a retired officer must wait until running for public office from one year to three years. ${ }^{229}$ "The worsening relationship eventually came to a head on 22 April 1996 when Wasmosy dismissed Oviedo as head of the army. Oviedo refused to obey the order, provoking a serious political crisis."230

\section{INTERNATIONAL REACTION TO THE COUP}

General Oviedo had attempted to postpone the internal Colorado Party elections, which were to be held on Sunday, 28 April $1996 .^{231}$ The internal elections had already been postponed five times since their original date, which was on August $1995 .^{232}$

\footnotetext{
${ }^{228}$ Ibid. p. 191.

${ }^{229}$ Ibid. p. 192.

${ }^{230}$ Ibid.

${ }^{231}$ La Nación newspaper, 04-23-96. Menem se solidarizó con Wasmosy.

${ }^{232}$ NotiSur - Latin American Political Affairs, 05-03-96. Paraguay: Threat of Coup by Defiant General Averted. Analysts point out that the main catalyst for this crisis was political in-fighting prior to the Colorado Party internal elections for the party presidency. This is a key post in choosing the presidential candidate in the national elections. "Contenders for the top party post were vice president Seifart, who Wasmosy backed and who had been favored to win before the crisis with Oviedo erupted; Luis Maria Argaña, who was supported by allies of former dictator Stroessner; and Blas Riquelme, a business leader who was backed by Oviedo and was committed to working for Oviedo's nomination as the Partido Colorado's presidential candidate." Ibid.
} 
Besides this, the president was incensed with Oviedo because his allies in Congress had blocked the award of a big bridge-construction contract to a firm owned by Wasmosy's family. ${ }^{233}$ Moreover, Oviedo had been staging a public campaign against the president for several weeks. ${ }^{234}$ All of this came to a head on the morning of April $23^{\text {rd }}$ when Wasmosy signed decree calling for Oviedo's resignation as commander of the armed forces for insubordination. ${ }^{235}$ The general, in turn, reacted by retreating to his military headquarters and told Wasmosy to resign while threatening to bomb the presidential residence unless a 7 p.m. deadline was not followed. "At this point, Wasmosy appears to have lost his resolve."236 Wasmosy apparently lost control of his country twice as he went into hiding at the US embassy in Asunción on Monday, the $23^{\text {rd }}$ and again on the following day as the bizarre episode unfolded, prompting observers to believe that Oviedo was orchestrating a coup. ${ }^{237}$

International reaction to the coup attempt was immediate, and turned out to be defining in preserving democracy in Paraguay. The presidents of Paraguay's MERCOSUR partners spoke to each other and to President Wasmosy on the first day of the crisis offering their full support. The permanent council of the OAS began a special session in its headquarters on Tuesday to discuss the situation in Paraguay, while Cesar Gaviria flew to Paraguay to help mediate the situation. ${ }^{238}$ The United States State Department expressed "serious concern" over the situation in Paraguay while the U.S.

\footnotetext{
${ }^{233}$ The Economist Newspaper. 04-27-96. Paraguay. Backward march. This article argues that Wasmosy is himself much to blame for the crisis since upon losing a party vote for the Colorado presidential candidacy in 1993, Wasmosy had turned to Gen. Oviedo who had the decision reversed. Later, and as a result, Wasmosy was unable to control Oviedo's frequent politicking. Ibid.

${ }^{234}$ Gazeta Mercantil, 04-23-96. International pressure against the coup in Paraguay.

${ }^{235}$ Facts on File World News Digest, 05-02-96. Constitutional Crisis Resolved.

${ }^{236}$ Nickson, 1997b: 192.

${ }^{237}$ Deutsche Presse-Agentur, 04-27-96. Paraguay's president was ousted twice in standoff with general.
} 
suspended military aid and threatened to suspend economic assistance should Oviedo take power. ${ }^{239}$ Foreign emissaries told Oviedo that Wasmosy's forced removal would not be tolerated by the international community. ${ }^{240}$

Within MERCOSUR, President Cardoso of Brazil summoned his military advisors to evaluate possible repercussions of the Paraguayan crisis. ${ }^{241}$ The Brazilian ambassador to England at the time, Rubens Barbosa, stated that Brazil, Argentina, and Uruguay would not hesitate to act if the dispute between Wasmosy and Oviedo deteriorated into a full-scale coup. Argentine Foreign Minister Guido Di Tella echoed that sentiment by asserting that if there was a coup, there would be immediate international isolation for Paraguay. ${ }^{242}$ At stake for MERCOSUR in particular was its international credibility as a regional bloc. ${ }^{243}$ Granted, a Paraguayan departure from the trade union would mean little to the region in economic terms given Paraguay's small size and limited economic importance, but politically it would have meant a serious setback for MERCOSUR. The 1990 Act of Buenos Aires accord between Argentina and Brazil, which later in 1991 incorporated Paraguay and Uruguay when they joined MERCOSUR, had asserted that democracy was considered to be an essential element for regional integration in the Southern Cone. ${ }^{244}$ Only by showing credibility could

\footnotetext{
${ }^{238}$ Xinhua News Agency, 04-23-96. OAS Permanent Council meets on Paraguay.

${ }^{239}$ Ibid.

${ }^{240}$ Nickson, 1997b: 192.

241 Xinhua News Agency, 04-23-96. Brazil evaluates crisis in Paraguay.

${ }^{242}$ NotiSur - Latin American Political Affairs, 05-03-96. Paraguay: Threat of Coup by Defiant General Averted.

${ }^{243}$ La Nación, 04-24-96. Un sobresalto en el sen del Mercosur. By Enrique Comellas.

${ }^{244}$ Ibid. Comellas adds that the democratic basis of the MERCOSUR is only the second of its kind after the European Union.
} 
MERCOSUR become a trustworthy partner for other countries and blocs, in turn becoming a more attractive area for foreign investment and so on. ${ }^{245}$

Representatives from the MERCOSUR countries, the OAS, the US and several representatives from countries in the Rio Group were present for the intense negotiations that occurred during the Wasmosy-Oviedo stand off. ${ }^{246}$ At the time of the Oviedo threat, Wasmosy had been ready to resign, but neighboring South American countries went as far as to offer Wasmosy military support if it was necessary. ${ }^{247}$ An agreement was reached whereby Oviedo would receive the post of defense minister in exchange for his resignation. Yet, OAS leaders as well as opposition Paraguayan parties in Congress rejected the bargain. On the night of April 24, thousands of demonstrators from opposition parties, labor unions and student groups, angered by this decision, clamored that democracy was being compromised and called for the president to reverse the decision. Claiming that popular displeasure with the decision made him break his commitment with Oviedo, Wasmosy rescinded on his offer a few days later and Oviedo did not receive the cabinet post after all. On the following day, Oviedo launched his 1998 presidential campaign, calling himself of all things 'a soldier of democracy'. ${ }^{248}$

\section{THE SHORT-LIVED CUBAS PRESIDENCY}

In what was seen as the first of many administration changes following the crisis, on April 27 [1996] Finance Minister Raul Cubas Grau resigned. Although he had only been in office for ten days, he was a staunch Oviedo

\footnotetext{
${ }^{245}$ Ibid.

246 Ibid.

${ }^{247}$ Facts on File World News Digest, 05-02-96. Constitutional Crisis Resolved. Despite the fact that the Air Force and Marines supported Wasmosy, 32 of 42 army generals supported Oviedo. This was significant because the army accounted for $70 \%$ of the country's armed forces.

${ }^{248}$ Ibid. Their italics.
} 
supporter and was thought to be heavily involved in the move to oust the president. Wasmosy named Carlos Alberto Facetti to succeed Cubas Grau. $^{249}$

The crisis over and in full control, Wasmosy proceeded to sack 21 military officers, 11 generals and 10 colonels, all key Oviedo supporters. ${ }^{250}$ Later, in December 1996, in a further attempt to bring the armed forces under his full control, Wasmosy dismissed another 225 officers who had remained loyal to the ex-general. ${ }^{251}$ Wasmosy also tried to bring Oviedo to justice. Interestingly, during a 1996 Congressional inquiry about the aborted coup, Oviedo defended himself by claiming that he had not initiated the coup but had acted in opposition to a Wasmosy self-coup, for which, according to Oviedo, Wasmosy had sought his support. ${ }^{252}$ In order to prevent Oviedo from seeking the Colorado nomination for the 1998 presidential election, Wasmosy tried to bring him to justice by having a military tribunal convict Oviedo for rebelling. After serving 55 days in prison on charges of insubordination and sedition, the Asunción Appellate Court ordered Oviedo released on 8 August $1996 .^{253}$ Soon after his release he formed a new faction within the Colorado Party, the Union Nacional de Colorados Eticos (UNACE), and announced that he would run for president in the 1998 elections. ${ }^{254}$

\footnotetext{
${ }^{249}$ NotiSur - Latin American Political Affairs, 05-03-96. Paraguay: Threat of Coup by Defiant General Averted.

${ }^{250}$ Defense \& Foreign Affairs' Strategic Policy, May, 1996. Paraguay.

${ }^{251}$ The New York Times, 01-01-97. Paraguay Uprising Costs Soldiers Jobs.

${ }^{252}$ Christian Torres. Inter Press Service, 06-06-96. Oviedo Accuses Wasmosy of Fostering Coup Attempt. Wasmosy had apparently become extremely frustrated with Congress since it had failed to act on any significant legislation to liberalize the Paraguayan economy.

${ }^{253}$ NotiSur - Latin American Political Affairs, 02-07-97. Paraguay: President Juan Carlos Wasmosy Engulfed in a New Dispute with Dissident General.

${ }^{254}$ Ibid.
} 
Cleared of these charges, Oviedo started his campaigning for the 1998 presidency throughout the Paraguayan countryside. Oviedo was very popular in the interior given his humble upbringing, fluency in the Indian Guarani language, and because of several public works projects in the region that were financed through the military budget. ${ }^{255} \mathrm{~A}$ charismatic speaker, Oviedo ran on a populist, anti-corruption platform. Unsurprisingly, Oviedo openly sought to maintain the military officer corps prerogatives. ${ }^{256}$ The campaign strategy worked, and in September 1997 Oviedo won the Colorado Party presidential primary by defeating Argaña as well as Wasmosy's hand picked candidate, Carlos Facetti. ${ }^{257}$ Wasmosy, however, responded by claiming that the elections were fraudulent. Paradoxically, he allied himself in this endeavor with Argaña, the man whom, with Oviedo's help, he had fraudulently defeated in the Colorado primaries several years before en route to the presidency.

Upon his return from visiting the Argentine and Uruguayan heads of state on October $3^{\text {rd }}$, Oviedo was handed a presidential order for 30 days of disciplinary prison for slanderous remarks that he made against Wasmosy. ${ }^{258}$ Oviedo went into 'hiding' and campaigned for 41 days, before finally turning himself in. On the eve of his scheduled release on January 1998, however, a court ordered him to be held indefinitely due to the continuing investigation of the 1996 uprising. ${ }^{259}$ Then, early in March, a military tribunal convicted Oviedo with rebellion for mobilizing troops in opposition to the president's

\footnotetext{
${ }^{255}$ NotiSur - Latin American Political Affairs, 05-03-96. Paraguay: Threat of Coup by Defiant General Averted.

${ }^{256}$ Arturo Valenzuela, 1997: 47.

${ }^{257}$ The New York Times, 09-24-97. Paraguay's Ruling Party Names Coup Suspect as Top Candidate.

${ }^{258}$ Gazeta Mercantil, 10-09-97. Wasmosy Sends Oviedo to Prison for Slanderous Remarks.

${ }^{259}$ Sebastian Rotella. Los Angeles Times, 01-24-98. Ex-General in Paraguay Makes Run for PresidencyFrom Jail.
} 
order to dismiss him and sentenced him with 10 years of prison. This military court ruling, however, had to be approved by the Paraguayan Supreme Court for Oviedo's candidacy to be nullified. ${ }^{260}$ With a worried eye on the Paraguayan situation, Brazilian president Cardoso expressed to Domingo Laino (Liberal Party and main opposition candidate in the 1998 elections), during his visit to Brasilia, the importance of the democratic clause of the MERCOSUR, "which demands institutional normality as a precondition for membership of the bloc.",261

In a 5-4 vote, the Paraguayan Supreme Court approved the Military Court's conviction of Oviedo for insubordination, and effectively nullified his candidacy as the Colorado Party's nominee for the presidential election. ${ }^{262}$ His running mate, Raul Cubas Grau replaced him as that party's candidate with Luís Maria Argaña (then party president) as his running mate. An apparent boost for the campaign of the main opposition candidate, Domingo Laino, was not enough to keep the Colorados from their reign in power as Cubas won the presidency on May 1998 by $54 \%$ of the popular vote. ${ }^{263}$

Only three days after his August $15^{\text {th }}$ inauguration, Cubas released Oviedo from prison by presidential decree. This caused a great deal of criticism, even from vicepresident Argaña, who called the decree an "exotic interpretation of the law". ${ }^{264}$ On August $20^{\text {th }}$, only five days after being inaugurated president, Congress members from both the opposition and Colorado parties petitioned Congress's lower house to initiate

\footnotetext{
${ }^{260}$ Carlos Montero. Inter Press Service, 04-14-98. Paraguay: Wasmosy Will Stand His Ground.

261 Ibid.

${ }^{262}$ The Associated Press, 04-17-98. Former General's Candidacy Ends as Court Upholds Prison Sentence.

${ }^{263}$ Stephen Brown. Manchester Guardian Weekly, 05-17-98. Ruling Party Wins Paraguay Elections.

${ }^{264}$ Facts on File World News Digest, 10-1-98. Cubas Sworn In as President. Their quotations.
} 
impeachment proceedings for abuse of power. ${ }^{265}$ The Oviedo issue would hound Cubas throughout his seven months in office. The ensuing episode climaxed with the tragic death of vice-president Argaña on May of 1999, and Oviedo's alleged involvement in it. Of particular interest to this thesis is the active role played by Brazil and Argentina during the aftermath of that crisis, and MERCOSUR's active involvement in Paraguay's internal politics.

\section{REGIONAL DIPLOMACY IN RESPONSE TO INTERNAL CRISES}

Several times during the crisis, [Brazilian President] Cardoso underlined that any rupture of the democratic systems would entail Paraguay's automatic expulsion from Mercosur, under the 'democratic clause' (formally, the Ushuaia Protocol) signed in mid 1996-appositely, in response to General Lino Oviedo's rebellion a few months earlier. ${ }^{266}$

At 8:50 a.m. on 23 March 1999, three gunmen murdered Paraguayan vicepresident Luis Maria Argaña, who was on his way to work. The gunmen, dressed in military fatigues, escaped the scene of the crime. ${ }^{267}$ Argana supporters and Senate President Luis González Macchi accused Cubas and Oviedo of being the masterminds behind the assassination. This resulted in a full-blown political and institutional crisis, "which triggered six days of violent clashes in which six people died and a further 130 were injured." 268 Those deaths and countless injuries occurred when snipers opened fire on the crowds during a March 26 manifestation in the capital's central square, in which

\footnotetext{
${ }^{265}$ Ibid.

${ }^{266}$ Latin American Weekly Report, 03-30-99. Solution of Paraguayan crisis was first success of Mercosur Democratic Clause.

${ }^{267}$ Tererè News, 03-30-99. Como Ocurrio el Brutal Atentado.

268 Agence France Presse, 03-30-99. Former Paraguayan president flees to Brazil.
} 
protestors for and against the impeachment were demonstrating. The snipers were believed to be members of Oviedo's UNACE faction. ${ }^{269}$

Prior to the assassination, it appeared that Cubas would emerge victorious from his impeachment struggle with Congress and the Supreme Court since it was unlikely that his opposition could garner the necessary two-thirds majority in Congress to unseat him. ${ }^{270}$ Yet, the tragic events that began with the Argaña assassination completely altered his situation. During the March 26 demonstrations, Cubas's police commander had ordered his forces to remain aloof to the sniper shootings, adding credence to those on the opposition that laid the blame of this malefaction to Oviedo, and by way of extension to Cubas. Cubas tried to remedy the situation by dismissing the chief of police, but he was unable to alleviate the tense atmosphere. Rumors of a coup spread as troops and an armored unit marched toward the capital. Meanwhile, Congress proclaimed that Cubas had two days to prepare his defense to impeachment charges for unconstitutionally pardoning Oviedo from his prison sentence seven months before. Late Sunday on March 28, hours before the congressional vote on his impeachment, Cubas resigned and on the following day was granted political asylum in Brazil. ${ }^{271}$

At the onset of the crisis, the Argentine and Brazilian ambassadors, U.S. and Vatican envoys, among others, all worked at finding a solution to this latest threat to Paraguayan democracy. ${ }^{272}$ The Brazilian ambassador to Paraguay, Bernardo Pericás,

\footnotetext{
${ }^{269}$ Latin American Weekly Report, 04-13-99. Andrew Nickson is quoted as he points out that the snipers were captured on camera and one man was arrested. He was linked both to this incident and the Argaña assassination. Ibid.

${ }^{270}$ Latin American Weekly Report, 03-30-99. Dramatic upheaval forces Cubas out. Their italics.

271 Ibid.

${ }^{272}$ Agence France Presse, 03-30-99. One day after stepping down, Paraguay's Cubas gets asylum in Brazil.
} 
kept in close contact with the warring parties in Paraguay, as attempts at a deal were hammered. F.H. Cardoso spoke to his MERCOSUR counterparts, Julio Sanguinetti of Uruguay and Carlos Menem of Argentina, as well as Bill Clinton of the USA with regards the crisis. ${ }^{273}$ Cardoso's role was decisive as a deal was reached whereby González Macchi became the head of a government of 'national unity', while Cubas and Oviedo were granted political asylum. "It was clinched by a personal telephone call from Cardoso to Cubas on Sunday, hours before the latter publicly announced that he was stepping down." 274

The Cardoso government witnessed the Paraguayan situations with grave concern, and went as far as putting its own military forces on alert should they be needed. ${ }^{275}$ Brazil sent 50 policemen and 30 marines, all armed with automatic weapons, to accompany Cubas and his family to a Brazilian air force plane. He was flown out of Paraguay and given political asylum in Brazil. Brazilian foreign minister, Luiz Lampreia, explained his government's decision by noting Paraguay's strategic importance to Brazil. Paraguay is home to over 300,000 Brazilians, is a Mercosur partner and is the site of the Itaipú plant. Lampreia added that his government ultimately sought Paraguayan stability, and that Cubas would not be allowed to involve himself in any political activity while in political asylum. ${ }^{276}$

\footnotetext{
${ }^{273}$ Tererè News, 03-30-99. Cardoso Tuvo un Papel Esencial para la Renuncia de Cubas.

${ }^{274}$ Latin American Weekly Report, 03-30-99. Solution of Paraguayan crisis was first success of Mercosur Democratic Clause.

${ }^{275}$ El Pais, Spain. 03-31-99. Brasil, EE UU y el Vaticano empujaron a Cubas a dimitir como presidente de Paraguay. Cardoso put his military on alert in order to protect the Itaipu hydroelectric plant from any potential damage, which is located at the border of these two countries, should the Paraguayan situation get out of hand. Consequently, the Itaipú plant provides $27 \%$ of Brazilian energy, including the states of Rio Grande do Sul, Paraná, Santa Catarina and Sao Paulo.

${ }^{276}$ Tererè News, 03-30-99. Cardoso Tuvo un Papel Esencial para la Renuncia de Cubas.
} 
It is of interest to this thesis that Brazilian armed security forces went into Paraguay to collect the ex-president. The Paraguayan situation was so serious that international diplomatic mediation was apparently not enough. The threat of force was thus a necessary component in Brazil's mediation. This threat was subtle in the form of an unlikely military intervention and overt in that armed guards went into Asunción to protect the well being of their out-going president. The differences of power between Paraguay and Brazil are unquestionable, and Brazil's stake in the former's stability has been pointed out, but is it the fact that both are MERCOSUR partners the main reason why Brazil did what it did? To put it differently, without MERCOSUR would Brazil intervene in this manner? To speculate, I would argue that it would have for the simple reason that they share the Itaipú plant, which is significantly important to Brazil. Brazil was playing its role of sub-regional hegemon. As the most powerful country of the region, its influence carries a certain undeniable weight in situations of this nature. It is noteworthy that at the hemispheric level, the clear hegemonic power is the United States. At the sub-regional level, the Southern Cone for instance, the most powerful states step up their efforts to intervene in local international crises. This is in fact very consistent with the present global emphasis on joint regional action to resolve crises that go beyond the control of a single government. In this context, it seems only natural that this multilateral action is to be led by the strongest regional actors. One could then argue that more than anything else Brazil was exercising its hegemonic sub-regional role, one that is facilitated by the present global environment of regional multilateralism. Membership in MERCOSUR also justifies and facilitates Brazilian, and Argentine, intervention in Paraguayan during crisis situations. Furthermore, common membership to MERCOSUR 
provides Brazil with added incentives in Paraguayan stability, as it is necessary for the bloc to maintain its international image as an organization that is backed by democratic governance. MERCOSUR may increase the interaction and interests between these countries, but it does not change the fact that the other Mercosur members view Paraguay with distrust. This is witnessed by the fact that the Paraguayan military has yet to participate in joint military exercises with the other Mercosur countries. ${ }^{277}$ The author believes that this was a case of finding a 'salida' (way out) to this latest Paraguayan institutional crisis by whatever means possible. A salida is not a solution, per say, but has been an interesting Latin American theme during crisis situations when an immediate solution is not feasible and finding an immediate exit from the crisis becomes imperative.

On the same day that Cubas was granted political asylum in Brazil, Oviedo was transferred to Argentina under a similar arrangement. Argentine president Carlos Menem confirmed that before granting Oviedo asylum, he consulted with the foreign ministries of the other Mercosur members. ${ }^{278}$ According to an Argentine foreign ministry spokesman, Argentina consulted with the US, Bolivia, Chile and its Mercosur partners before making a decision. ${ }^{279}$ This was important because Oviedo fled the country, with criminal charges pending. Despite complaints on the Paraguayan side in this regard, Menem stated that Paraguay did not put forth a request of extradition for the ex-general, and that an extradition treaty between Argentina and Paraguay is non-existent. ${ }^{280}$

\footnotetext{
277 El Pais, Spain. 03-31-99.

${ }^{278}$ Clarín Digital, 03-31-99. Menem confirmó las consultas.

${ }^{279}$ Agence France Presse, 03-30-99. Former Paraguay general takes refuge in Argentina on political asylum.

${ }^{280}$ Ibid.
} 
Interestingly, the present government coalition of González Macchi apparently knew of an extraordinary military tribunal resolution (2/99), which gave Oviedo protective liberty so that he may seek asylum in Argentina, and kept it silent. ${ }^{281}$ Macchi claimed no knowledge of it as his incoming government hurriedly faxed the Argentine Foreign Ministry an extradition request for the former general. Curiously, Walter Bower, president of the Chamber of Deputies at the time, had knowledge of the resolution before the plaza shooting but made no mention of it in the following days. ${ }^{282} \mathrm{He}$ is presently the Minister of the Interior. This example lends itself to the theory that the incoming Paraguayan government in fact wanted Oviedo out of the country, and did not ever really intend to extradite him from Argentina. But why then the ensuing rift between the González Macchi and Menem governments with respect to the Oviedo issue?

\section{THE DETRIMENT OF PARAGUAYAN RELATIONS WITH ARGENTINA AND}

\section{$\underline{U R U G U A Y}$}

Insecurity and conflicts at the domestic level pose a dilemma for regionalism. In many ways these are the most serious conflicts confronting developing countries. They can also spill over into neighboring countries and strain interstate relations or give rise to interstate conflict with negative consequences for regionalism. ${ }^{283}$

The Oviedo asylum caused dissention within Argentine political circles from the onset. Vice-president Carlos Ruckauf stated that Oviedo should leave because former coup leaders are not welcome in Argentina. He was quoted "we do not want our country

\footnotetext{
${ }^{281} \mathrm{ABC}$ Color, 4-15-99. Cúpula gobernante sabia que huyó Oviedo.

282 Ibid.

${ }^{283}$ Alagappa, 1995: 174.
} 
to conspire against Paraguay., 284 On the other hand, the former president and member of the opposition Radical Party, Raúl Alfonsín, agreed with Menem's decision arguing that a service was being provided to Paraguayan democracy. ${ }^{285}$ Alternatively, Fernando De la Rua (currently the Argentine president-elect and also a Radical) disagreed with Menem's decision. Argentine Deputy Foreign Minister, Andrés Cisneros, justified his government's decision by stating that it was based on a desire to keep MERCOSUR's political image from being damaged throughout the world, fearing an unconstitutional political change in Paraguay. ${ }^{286}$

On April 30, the Uruguayan government granted political asylum to José Segovia Boltes, a retired general and minister of defense during the Cubas administration. Boltes claimed that he and his family were in danger due to political persecution and threats. Boltes, an ardent Oviedo supporter, was being sought after by Paraguayan authorities for allegedly embezzling US $\$ 400,000$ of public funds while serving as defense minister. ${ }^{287}$ While acting as interim president (González Macchi out of the country, taking part in an economic summit in Chile), Paraguayan Senator Juan Carlos Galaverna criticized the Uruguayan government of having hypocritical relations with his country and accused the Argentine ambassador to Asunción, Néstor Auad, of being an Oviedo collaborator. Both the Argentine and Uruguayan governments expressed their displeasure with those comments. The Uruguayan government went as far as to state that since Paraguay occupied the pro tempore MERCOSUR presidency they would refuse to attend the

${ }^{284}$ Tererè News, 03-30-99. Vicepresidente pide un gesto a Oviedo: "Que se vaya". Quote translated from Spanish and taken from this article.

${ }^{285}$ Clarín Digital, 03-31-99. Menem confirmó las consultas.

${ }^{286}$ Telam News Agency, 03-30-99. Argentine minister says Oviedo asylum decision was to protect Mercosur. 
Asunción summit meeting in July. ${ }^{288}$ The Uruguayan ambassador to Asunción was recalled as a further sign of the deteriorating relations between these two governments. ${ }^{289}$ It took a telephone conversation a few weeks later between Luis Sanguinetti and Macchi to partially remedy the situation.

The inviolability of asylum in favor of those persecuted for political reasons was established in the 1889 Montevideo Treaty of International Penal Rights. Moreover, The American Declaration of Rights and Duties of Man (Bogotá, 1948), and the American Convention on Human Rights (San José, Costa Rica in 1969) guarantee all persons the right to seek and obtain asylum in a foreign country in the case that persecution is not motivated due to a common crime. ${ }^{290}$ This latter stipulation allows the country providing asylum a broad range of legal interpretation. The applicable Argentine law with respect to extradition is the International Cooperation in Penal Matters Law \#24.767. The executive can reject only extradition requests that are not presented in the proper legal manner. Once a request is properly made, article 111 of the above law establishes that the judiciary determines whether or not he is to be extradited. ${ }^{291}$

In Oviedo's case, the attempted coup is not a common crime and has political underpinnings, so that basis of Paraguay's request is negated based on the above treaties and agreements and his extradition should be refused. Another charge involved Oviedo's alleged involvement in the central plaza shootings after he apparently gave orders to Niño

\footnotetext{
${ }^{287}$ Tererè News, 05-03-99. Diputados explican su rechazo a concesión de asilo a Segovia.

${ }^{288}$ Clarín, 05-07-99. Paraguay, contra Argentina y Uruguay.

${ }^{289}$ Terere News, 05-09-99. Cancilleres de Uruguay y Paraguay inician el proceso para normalizar las relaciones.

${ }^{290}$ La Nación, 04-08-99. Editorial II, Oviedo y el asilo político.

${ }^{291}$ Marcelo Stubrin, La Nación, 09-10-99. Los valores en juego.
} 
Trinidad (the soon thereafter deposed police commander) to have his men stand idle. This, if proven, is an example of a common crime and not one of which Oviedo would unjustly be persecuted for political reasons. Based on that charge, the extradition should be granted.

In July 28, Paraguayan magistrate Jorge Bogarín González formally requested Oviedo's extradition based on an ongoing investigation regarding his alleged involvement in the Argaña assassination. ${ }^{292}$ Hailed as the first formal and serious Paraguayan request by Argentine government sources, presidency secretary Carlos Corach reassured his Paraguayan counterparts that the judiciary would treat the matter with impartiality. ${ }^{293}$ Amidst accusations that Oviedo was involved in political activity, which is prohibited during political asylum, on September $2^{\text {nd }}$ the Argentine Foreign Ministry rejected the Paraguayan extradition request. Foreign minister Di Tella signed the rejection without passing it to the judiciary, as should have been the case. This request was rejected on the basis of a stipulation in law 24.767 that impedes refugees to be sent to the country from where they sought refuge. Yet, Lino Oviedo was granted political asylum, and therefore was not a refugee. ${ }^{294}$

Almost simultaneously, the Uruguayan government rejected a Paraguayan extradition request for José Boltes, which was based on charges that he too was involved in the Argaña murder. The González Macchi government expressed its indignation stating that Argentina and Uruguay were obstructing proper Paraguayan judicial procedures while contributing to impunity at a time when Paraguay attempted to

\footnotetext{
${ }^{292}$ La Nación, 07-29-99. Un juez paraguayo pidió la extradición de Lino Oviedo.

${ }^{293}$ La Nación, 08-04-99. Oviedo no contaria ya con el respaldo argentino.

${ }^{294}$ La Nación, 09-05-99. Oviedo un alto costo político.
} 
consolidate its democracy. To Macchi, these gestures could only impede the common process of regional integration. ${ }^{295}$

The results of the rejection to the Oviedo extradition request were on the whole negative for the bilateral relations between Argentina and Paraguay. Members of the Alianza coalition (made up of the Radical and Frente Solidario del País [FREPASO] parties) solicited a political lawsuit against Di Tella for his rejection to the request. This request was based on article 15 of the Montevideo Treaty, which establishes that any extradition request has to be passed on to the judiciary. ${ }^{296}$ In Paraguay, Macchi asked for the resignation of Foreign Minister Miguel Abdón Saguier. Further, the Paraguayan ambassador to Buenos Aires, Leila Rachid, was recalled to Asunción. ${ }^{297}$ What ensued was a mud slinging campaign between the respective governments. Among those accusations, the most serious one involved Paraguayan Senator Luis Alberto Mauro who accused Menem, Argentine Defense Minister Jorge Domínguez, and Oviedo of being involved in corrupt business activities that included fraudulent use of funds, originating from the World Bank and the Inter-American Development Bank, that were intended for joint construction of the Yacyretá dam. ${ }^{298}$ After categorically denying these allegations, Menem demanded an apology from the Paraguayan government, which he did not receive. To make matters worse, an agreed upon September 9 meeting between the two heads of state to discuss the Oviedo issue was cancelled at the last minute. Menem pointed out that his government's posture regarding the Oviedo issue would now be more

\footnotetext{
295 La Nación, 09-04-99. González Macchi: un gesto inamistoso.

${ }^{296}$ La Nación, 09-04-99. Solicitan el juicio político de Di Tella.

297 La Nación, 09-04-99. Paraguay llamó a su embajador en la Argentina.

${ }^{298}$ La Nación, 09-10-99. Yacyretá sigue bajo la lupa.
} 
rigid given the insults that several Paraguayan legislators and functionaries threw his way. To date, the Oviedo asylum issue has not been resolved.

Maybe the best way out of the current impasse was suggested by Macchi when he stated that the extradition requests to Argentina and Uruguay will be suspended until there is a more propitious climate to do so, meaning after new presidents take office in the respective countries at the end of the year. ${ }^{299}$ Interestingly, deposed Paraguayan foreign minister, Miguel Saguier, suggested that the accusations handed to Menem by Paraguayan legislators have a double intent, namely that Oviedo not be extradited. ${ }^{300}$ Argentine interior security secretary, Miguel Angel Toma, similarly expressed that Paraguayan authorities have been hypocritical in that they continually ask for Oviedo's extradition, while sending covert messages telling the Argentine government to not even think about sending Oviedo back to Paraguay. ${ }^{301}$ It will be interesting to see what the De la Rua government does with respect to this issue. I believe that Macchi's bluff will be called and Oviedo will be sent back to Paraguay or to another country. One has to worry about what the consequences of an Oviedo return to Paraguay would mean for the fragile and turbulent democratic transition that this country is undergoing. It should not be forgotten that this man has been the main threat to Paraguayan democracy by bringing this country to the brink both in 1996 and in 1999. Moreover, he and his allies have played a role in disrupting Paraguayan relations with Argentina and Uruguay. It is no less disconcerting that the people running Paraguay at the moment are for the most part former allies of General Stroessner.

\footnotetext{
${ }^{299}$ La Nación, 09-04-99. Paraguay llamó a su embajador en la Argentina.

${ }^{300}$ La Nación, 09-10-99. Sospechas de Saguier sobre denuncias de legisladores.

${ }^{301}$ La Nación, 10-05-99. Toma: Paraguay tiene doble mensaje.
} 


\section{CHAPTER 4}

In order to take on a security role, regional organizations would need to overcome an obstacle and resolve a paradox. They would need to possess the requisite financial, institutional and military capability to play a regional conflict management role. Regional arrangements would also need to be synchronous with the regional security complexes which emphasize the interdependence of rivalry as well as that of shared interests. That is, all parties that are central to a regional security complex must be included within the regional arrangements for the latter to have any real meaning. ${ }^{302}$

This concluding chapter is divided into two sections. The first section examines salient security issues among the MERCOSUR countries. I will discuss advances as well as setbacks that have emerged in the relations between the MERCOSUR members (this includes associate members as well, as Argentine-Chilean relations will be discussed) within the framework of integration and increased interaction. This is done in keeping with the central question, which asks whether regional economic integration is conducive to the establishment of cooperative security mechanisms.

The concluding section of this thesis analyzes and qualifies the stated central question of this project in light of the evidence that has been presented. Some salient regional trends in the security arena will be revisited as I attempt to determine the impact that these may have, not only on the internal processes of democratization these countries are undergoing, but how these trends affect and bring into play other regional actors. The hegemonic regional role played by the United States will also be discussed given its lead in multilateral intervention throughout the hemisphere. For the purposes of this thesis, it is worth noting that US initiatives temper the unilateral and multilateral actions of the 
Southern Cone countries, as they attempt to alter their own regional strategic balance. In the present post Cold War context, the Paraguayan case is one of many recent examples that demonstrate the prominent leading role by the US and the OAS in promoting democracy as well as collective action toward the resolution of "common" threats to security in the region. I will conclude that the Paraguayan case also shows that the main MERCOSUR countries have come to increasingly assert their influence at the subregional security level, and may come to play a much larger security role if the present nature of inter-American relations continues.

\section{POST COLD WAR SECURITY IN THE SOUTHERN CONE}

The implementation of integration treaties brings into question old conceptualizations of traditional conflicts among neighboring countries. If these agreements are successful and permanent supranational institutions develop, a debate concerning what types of armed forces and defense policies are called for under such new conditions will become inevitable. ${ }^{303}$

Is economic integration conducive to security cooperation? The obvious answer would appear to be yes, yet neither the Chilean nor the Brazilian governments were particularly happy for Argentina when it was named an extra-NATO ally of the United States in mid-1997. Do these governments still view each other with distrust? I would argue that they do and this may be cause for concern given that democracy is not completely consolidated anywhere in Latin America, and neo-liberal economic policies, despite initial macroeconomic successes, are having serious societal repercussions such

302 Thakur, 1997: 71.

${ }^{303}$ Millet and Gold-Biss, 1995: 68. 
as dangerously high levels of unemployment even in the most developed countries of the region.

Upon learning that Argentina had been named an extra-NATO ally of the U.S., Chilean foreign minister José Insulza flew to Washington immediately to express his government's concern over this matter. He did this despite the fact that Menem had an interview with [Chilean president] Eduardo Frei the day before to forewarn Chile of the upcoming U.S. decision. Di Tella did the same thing with Brazil, Argentina's main strategic ally. Jorge Dominguez stated that this newly acquired status did not mean that Argentina would attain ultramodern weapons from the U.S., despite Chile's interest in purchasing F-16 airplanes from the United States. ${ }^{304}$ Chilean fears were not unwarranted, however. During a visit from Argentine General Martín Balza to General Charles Wilhelm of the U.S. Southern Command, the 'new military roles' against narcotics trafficking and terrorism were discussed, as was the possibility of Argentina's ability to purchase certain military equipment given its extra-NATO ally status. ${ }^{305}$ The end of the U.S. arms embargo to Latin American countries facilitates the sale of modern weaponry to these nations.

With respect to this issue, there are recurring fears that the sale of modern weaponry to Latin America will divert funds from other programs, exacerbate existing tensions, and risk re-igniting arms races. ${ }^{306}$ Jimmy Carter, who established the arms prohibition during his presidency, argued that lifting the ban would open up a Pandora's box in the region. Also, Bernard Aronson, undersecretary of state for Latin American

\footnotetext{
${ }^{304}$ Clarin, 8-14-97. Luz verde a una alianza militar.

${ }^{305}$ Clarin, 2-18-98. Balza recibió elogios del jefe del Comando Sur de EE.UU.

${ }^{306}$ Millet, 1997: 125.
} 
Affairs during the Bush administration, stated that surely this will plant the seeds for an arms race and will cause problems for Argentina, which is one of the best U.S. allies in the region. ${ }^{307}$ Others, like U.S. secretary of state William Cohen, retort that Latin American countries must modernize their armed forces and that a prohibition of weapons sales on the part of the United States, within the democratic context of the region, would be paternalistic. Of course, there is a substantial economic interest on the part of the U.S. weapons industry, which contributed US $\$ 11$ million to Clinton's re-election campaign. ${ }^{308}$

Senator Jose Sarney of Brazil was quoted "we can not accept new military expenses; we have other priorities. But if our neighboring countries do so, we can not refrain from doing so ourselves." ${ }^{, 309}$ In the context of civil-military relations, it is noteworthy that arms production has a higher level of correlation with the degree of political power exercised by the armed forces than do budgets. ${ }^{310}$ One could argue that arms purchases may have a higher correlation still.

It becomes apparent that there are serious obstacles for security integration in the Southern Cone. Political corruption and social inequalities do not bode well for regime stability. ${ }^{311}$ Sub-regional trade integration as a cooperation paradigm also brings up a number of pragmatic considerations that could impede security cooperation. "Since so many prospective trade partners were once perceived as the enemy by militaries that perennially planned to defend against territorial aggression, the shift to defense cooperation with the same nations implies a fundamental redefinition of the strategic

\footnotetext{
${ }^{307}$ Christopher Marquis, El Nuevo Herald, 6-6-97.

${ }^{308}$ Ibid.

${ }^{309}$ Ibid.

${ }^{310}$ Acuña and Smith, 1996: 225.

311 Thomas Sheetz, 1996: 407.
} 
environment." ${ }^{, 312}$ It can be safely be stated that an arms race between the Southern Cone MERCOSUR countries would impede any and all efforts that have been made to shift the strategic paradigm from one of distrust and competition to one of cooperation and understanding. Several strategically important countries, like Brazil and Peru, have refused to sign the Non-Proliferation Treaty, and that it would be possible, though unlikely, for Argentina and Brazil to renew their efforts to develop missiles or weapons of mass destruction if their domestic regimes were to change in the future. ${ }^{313}$

Regarding Argentine-Chilean relations, there have been significant improvements in the last few years. In February of this year, these two countries finally resolved the last of their original 24 territorial disputes. Also, during a February 16 presidential meeting, Frei stated that Argentina's extra NATO ally status does not break the regional equilibrium with respect to strength and military equipment. In fact, both governments reached an unprecedented agreement to audit each other's military expenditures beginning in the year 2000. The mediation rules for this are to be established by the Economic Commission for Latin America and the Caribbean (ECLAC) of the United Nations. $^{314}$ The Argentine and Chilean navies also began joint military exercises in August 1998. At the time, Argentine admiral Carlos Marrón expressed pride in the exercises and stated that these initiatives help break the common logic of suspicion and antagonism. ${ }^{315}$ Moreover, if the auditing of military expenditures actually occurs it will mark a huge turning point in the military relations of these two countries, who almost went to war twenty-one years ago. Frei stated that since the last Argentine-Chilean

\footnotetext{
${ }^{312}$ Downes, 1996: 7.

${ }^{313}$ Albert Coll, 1997: 49.

${ }^{314}$ Pablo Calvo. Clarín, 02-17-99. Acuerdo con Chile para controlar gastos militares.
} 
territorial dispute is resolved, the economic association could now be furthered. ${ }^{316}$ In this case at least it appears that security cooperation will result in further economic integration, and not vice versa. Then again, Chile is already an associate member of MERCOSUR.

Alternatively, relations between the two main MERCOSUR countries, Argentina and Brazil, have steadily deteriorated within the past year. The February Brazilian devaluation affected the entire region, and Uruguay and Paraguay expressed their discontent to this as well. Due to the devaluation, Brazilian exports have been cheaper and have consequently flooded its partners' markets, while it has become more expensive for them to export to Brazil. There is an ongoing case, now being handled by the World Trade Organization (WTO), regarding the imposition of Argentine trade barriers to Brazilian textile products, which the Brazilians claim is a violation to the Common External Tariff (CET) of the agreement. This case has gone to the WTO because the respective governments failed to negotiate an agreement, and there is not a supranational court in MERCOSUR to handle disputes of this nature. Also, the Brazilian government became incensed when on August 8, the Menem administration formally applied to NATO for consideration as an associate member. "Itamaraty [Brazilian Foreign Ministry] noted that it had not been consulted, and that such a development 'would introduce extraneous elements into the context of South American regional security'.,317 Of concern to Brazil is that Argentina's active diplomacy in the context of a redefining international security system will give it an advantage over Brazil in their competition

315 Telám, Ushuaia, 08-10-98.

${ }^{316}$ Pablo Calvo. Clarín, 02-17-99. Acuerdo con Chile para controlar gastos militares.

${ }^{317}$ Southern Cone Report, 08-03-99. Menem applies for Nato link. 
over a permanent seat on the UN Security Council. ${ }^{318}$ The crisis sparked by the Argentine request soon made it to the commercial area. The Argentine application was rejected by NATO.

In light of the De la Rua victory in the Argentine October presidential elections, the Brazilian government wants to look past the NATO issue. Asked about ArgentineBrazilian military relations, Luiz Lampreia responded that "Argentina's request to join NATO has not facilitated relations but I think the issue is over and I live in hope that we shall talk again about a military rapprochement and carry out the planned joint military exercises. ${ }^{319}$ According to a high level Brazilian government official, between eight and nine government ministries have direct interests in Argentina. ${ }^{320}$ Therefore, these latest Argentine presidential elections were viewed as critical to Brazil and its relations with its neighbor, particularly in light of the tense relationship these two have had in the past months. Brazil is concerned about Argentina's flirtation with dollarizing its economy. In fact, they are more fearful of this than an Argentine devaluation. "It is not possible to have a Mercosur partner whose monetary policy is determined by the Federal Reserve of the U.S. It would be a total retreat for the bloc. We could not even think about coordinating macroeconomic policies." ${ }^{, 321}$

The Brazilian government views the Argentine change of government with optimism. They contend that a re-launching of Mercosur is necessary, and that with a new government in Argentina this is possible. Included in this proposed re-launching is a

\footnotetext{
318 Ibid.

${ }^{319} \mathrm{BBC}$ Summary of World Broadcasts, 10-15-99. Brazil to propose Mercosur relaunch to new Argentine government, minister says. Original source 'O Estado de Sao Paulo' 10-13-99.

${ }_{320}$ La Nación, 10-24-99. Descuentan en Brasil la victoria de De la Rúa.

${ }^{321}$ Ibid.
} 
political commitment to the bloc in an operational sense, which includes rescuing abandoned aspects of the original agreement. These include macroeconomic coordination, as well as integration in areas such as services, government procurement and the labor market. Brazilian Senator José Sarney stated that the future of the bloc depends on a reformulation of MERCOSUR's underlying concepts, as well as putting the creation of a common market back on the agenda. ${ }^{322}$ Brazil is also content that De la Rúa plans to emphasize his country's foreign policy more on its MERCOSUR partners and Europe and less on the United States. The Brazilian government believes that De la Rúa is more pro-MERCOSUR than Menem. They are also encouraged that the incoming government will handle the Oviedo issue differently and hope that relations between Argentina and Paraguay can normalize. This is key, according to a high-ranking Brazilian functionary, because he believes that the discord between Menem and González Macchi has given the bloc a negative impression to the international community. ${ }^{323}$ In any case, with cautious optimism MERCOSUR prepares to enter a new era in its development.

\section{CONCLUSION}

The central question of the $21^{\text {st }}$ century has become: will the nations of Latin American define their security in strictly national terms? Or in terms which take advantage of, or require some measure of, regional cooperation or integration? $?^{324}$

\footnotetext{
${ }^{322}$ Mario Osava, Raul Ronzoni and Gustavo Gonzalez. Inter Press Service, 10-26-99. Argentina: President-elect welcomed by MERCOSUR partners.

${ }^{323}$ La Nación, 09-11-99. Brasil prefiere quedarse al margen.

${ }^{324}$ Tulchin, 1997: 39.
} 
This thesis asks what and the MERCOSUR case in general, and the Paraguayan case in particular, tell us about the relationship between economic integration and security cooperation. The central question asked whether a causative relationship exists from the economic side of integration onto the security dimension. In light of the evidence that has been presented, it appears that this assumption requires some qualification. To state that the integrative flow necessarily goes from the economic arena to the security sphere depends in fact on which region or bloc one analyses. In the case of the European Union, which was briefly discussed in the first chapter, other institutions such as NATO had, during the Cold War, played the predominant security role in the region. Even after the ending of the Cold War, NATO continued to be the primary international interlocutor in security issues, as evidenced in the U.S. role in the both Balkan wars. Yet, the Europeanist logic has gained currency as witnessed by the 1993 Maastricht Treaty, which called for the EU to play more of a political and security role in this new international context. Still, the EU and even the WEU continued playing minor roles in this sphere, and the idea of applying supranationality to security issues was seen as being too much of an impingement on the sovereignty of these nations. Only very recently has the idea of a stronger EU role in security issues become a reality, in the sense that it plans to move away from the U.S. sphere of influence, and admits some loss of sovereignty on the part of its members. As was pointed out in the first chapter, beginning next year there will be a security czar who will speak for fifteen European countries, who will be backed by a stronger WEU force in case of future occurrences like the Kosovo crisis. Is this case proof that economic integration has led to common security in that region? Or is it proof that the end of the Cold War has altered and redefined the global 
strategic environment? I believe the latter is the case due to two reasons. First, the U.S. is in the process of diminishing its global military presence and wants other countries and regional actors to step up their efforts to defend their own interests instead of simply depending on the U.S. to bail them out. This is not to suggest that the U.S. wants to redefine its hegemonic role, but that it no longer has the resources nor the will to become involved in every international crisis, only the ones that it views are in its national security interests. Second, the United Nations, while a leader in global multilateral action, has recently voiced its desire for regional actors to play a bigger role in resolving dilemmas within their regions. Both the U.S and U.N. continue to lead global multilateral initiatives, but are encouraging more regional action and less dependence on their leadership, and more importantly, their resources.

In the case of ASEAN (a regional arrangement more comparable to MERCOSUR since its members are developing countries and it is a sub-regional arrangement), increased economic interaction was the justifying component of this organization while the real raison d'etre was covert cooperation in security and political issues. Based on that, it cannot be argued that economic integration led to security cooperation in ASEAN either. The economic logic to integrate was there before the end of the Cold War. This was not the case in the politico-security realm. With the end of the Cold War, and its backdrop of capitalism versus communism over, these nations can more openly engage in security dialogues. The catalyst appears to be the ending of the Cold War, and not regional economic organizations. The latter provided the essential institution building and networking processes that facilitate interaction in other dimensions, but the strategic redefinition was not possible without the ending of the Cold War. 
The MERCOSUR case is complex. These countries are undergoing democratic transitions that are distinct and in different stages. It would be easy to argue that if not for its MERCOSUR membership, Paraguay would have fallen back to authoritarianism either in 1996 or in 1999, even though the U.S. and the OAS would have never permitted that. Still the involvement of its main partners, Argentina and Brazil, has been defining to the transition process this country is undergoing. Cubas is in Brazil, and Oviedo, who is the real power holder, is in Argentina. The members of MERCOSUR, an economic organization, intervened in two critical institutional crises in this country and democracy was preserved. It is tempting to say that the democratic clause has been a great success and Paraguay is the proof. It is also tempting to argue that this case shows that in the Southern Cone, economic integration has resulted in security cooperation, and intervention when necessary. Yet, I believe that MERCOSUR is not so much an economic organization as it is a political union based on an imperfect customs union.

The gains of forming this customs union with a CET are evidenced from the impressive growth of mutual trade between these countries, especially in the first years of the organization. This occurred despite hard adjustment costs and poor trade infrastructure. "But the real motivation for the formation of MERCOSUR has been fear of other groupings like the EC and NAFTA and the desire to improve bargaining capacity."325 The MERCOSUR is born out of strategic considerations in both Brazil and Argentina. The MERCOSUR members believe it is in their best interests to integrate, in great part to improve each country's individual bargaining capacity. With respect to the application of neo-liberal policies, Gautam Sen offers: 
The underlying economic catalysts of liberalization and its corollary, globalization, precede the subsequent causative political factor of the ending of the cold war as a matter of empirical fact. In virtually all cases the immediate reason for the adoption of liberalization programmes has been a balance of payments crisis and a collapse of the exchange rate, usually accompanied by inflation and an unsustainable fiscal deficit. ${ }^{326}$

Regarding economic integration and security cooperation, we are looking at two separate processes that have different catalysts. The impulse toward economic integration has its roots in the process of globalization and its attendant consequences. The desire and necessity to coordinate foreign policies to combat common threats to security is derived from the end of the Cold War and the ongoing process of strategic international redefinition. The two processes are linked in many ways and temper each other, but are distinct.

When asked whether MERCOSUR will become institutionalized to the point where a supranational body exists, Argentine Mercosur undersecretary, Ambassador Alfredo Morelli stated that in the near future this is impossible. $\mathrm{He}$ argued that sovereignty is too important to the member countries. He also proposed that security issues do not necessarily fall into the realm of an organization that is economic in nature. When asked what the main sources of conflict were, Morelli stated that difference in size was the common divisive factor. His argument stems from an economic point of view. Yet, similar arguments could and have been made from security strategic points of view. The likelihood of Brazil attaining regional hegemonic status is real, as is the phenomenon

${ }^{325}$ Gautam Sen, 1999: 65.

${ }^{326}$ Ibid. p. 63. 
of free riding by the smaller nations. Morelli made that point succinctly and I believe it applies to security issues as much as it does to economic issues. ${ }^{327}$

I dissent from the view that MERCOSUR is purely an economic organization. If this were the case, then why do nine Brazilian ministries have direct interests in Argentina, instead of just the Ministry of Economy and the Ministry of Foreign Affairs? MERCOSUR is a political project, founded upon economic principles and democracy. MERCOSUR inserts its members into the global economy, giving them a stronger voice in defining the post Cold War security environment of the hemisphere. Despite obvious competition, these countries have decided that there is no alternative to integration. This is shown by the fact that a center-left coalition won the presidency in Argentina, and Mercosur membership was not an issue. Unemployment and crime were important issues, but with respect to MERCOSUR, the main candidates of that election called for strengthening the bloc, as well as moving away from the U.S. sphere of influence. In Uruguay, both presidential candidates that will face off in the November 28 runoff plan to stay within the parameters of integration. Tabaré Vasquez, who heads a coalition of left-leaning parties that includes former Tupamaro guerrillas, if victorious wants to capitalize on the De la Rúa victory and a possible Lagos victory in Chile, who is also on the left. Argentine Vice-President elect Carlos Alvares of FREPASO stated that "there is a common agenda in Latin America, and I believe that we, along with Lagos and Tabara (Vazquez), interpret it in a similar manner. I am talking about how to address the problems of growth, equality, social equity and greater solidarity." ${ }^{328}$ It appears that

\footnotetext{
${ }^{327}$ Interview with Ambassador Alfredo Morelli, 03-20-98.

${ }^{328}$ Mario Osava, Raul Ronzoni and Gustavo Gonzalez. Inter Press Service, 10-26-99. Argentina: President-elect welcomed by MERCOSUR partners.
} 
while the emphasis on what problems predominate is tempered by ideology, all see cooperation as part of the solution.

In light of the trends that were pointed out in the second chapter, namely the militarization of policing functions, there are serious challenges to the region. Neoliberal economic policies have brought on macroeconomic fiscal stability, but have resulted in the further impoverishment of the poor and increased unemployment. This has resulted in an increase in crime in every country, including Uruguay. As has been implemented in Brazil and Paraguay and has had serious proposals in Argentina, the Uruguayan government has flirted with the idea of providing its military with police functions to attend to rising crime and police corruption. ${ }^{329}$ This trend is a result of the inability of the state in the present neo-liberal context to protect its populace. Thus, the government turns to the military when crime becomes overwhelming, as happened in Brazil in 1994 and 1995, while middle and upper class society purchase private security. We cannot forget that there is an Argentine project that proposes to give private security officers 'limited' policing functions. Could we be headed toward the privatization of the traditional security role of the state as well? This question goes beyond this research but is worthy of further analysis.

There is often little agreement between the U.S. and its Latin American counterparts on the nature of what constitute common threats and even less on their resolution. While the U.S. continues to dominate in these issue areas, it has also portrayed an interest in lessening its international role while promoting multilateral action by regional actors. This policy is backed by proposals of this nature by the United 
Nations at the global level, and by the OAS in the Western Hemisphere. As the US role diminishes, it is becoming clear that other actors attempt to fill this void. In my view, in the Southern Cone, Brazil and, to a lesser extent, Argentina through their efforts during the Paraguayan crises have shown an inclination at playing a much greater regional role to fill the vacuum that a US retreat would leave. It may be the case that the ability for Latin American states to control, or inhibit, the individual actions of the U.S. will depend upon the their ability to cooperate with one another in regional or sub-regional groups. ${ }^{330}$ Mack and Ravenhill propose:

In the increasingly interdependent world of the 1990s, international 'regimes' have grown rapidly in number, in scope and in importance. They have evolved because policy-makers recognize that there are fewer and fewer unilateral solutions to the problems they confront across a range of foreign policy issue areas and thus there is an ever-increasing need for multilateral cooperation. ${ }^{331}$

This appears to be the case in the Southern Cone as one witnesses the developments that have been pointed out. It is also becoming apparent that the national territory can no longer be considered to be the only point of reference for the needs of nation-states in their security concerns. ${ }^{332}$ "It needs to be made clear that strategic cooperation in security matters must implicate the predominance of civil authority over that of the military.",333 The global and regional parameters have changed. "For developing nations, integrating with their neighbors may be the only viable manner in which they can insert themselves into the global economic and political context, and may

\footnotetext{
${ }^{329}$ Clarin, 07-29-97. Darán tareas policiales a las FF.AA. uruguayas.

${ }^{330}$ Tulchin, 1997: 39-40.

${ }^{331}$ Mack and Ravenhill, 1995: 1. They define regime as those multilateral arrangements that are created to facilitate international cooperation. Ibid.

${ }^{332}$ Ambler Moss, 1995: 15.
} 
improve each country's bargaining position in dealing with more powerful countries and blocs." 334 Given this, I believe that this project has shown that a causative relationship does not necessarily exist between economic integration and security cooperation. Yet, this research has shown that these two processes are linked and temper each other on a procedural basis. When commercial relations are going well, there is higher likelihood that cooperation in the security arena will occur, and vice versa. Both processes are based on multilateral action in order to attain common economic and social goals and to combat common threats, this in the ambit of competition of course. Both processes are a response to global phenomena in the economic and security spheres. Thus, the correlation is obvious, as is the fact that these projects are based at the regional level. "Within a region there are some economies of scale and some possibilities for protection against the more merciless aspects of global competition." ${ }^{335}$ Barry Buzan offers:

The relevance of all of this for regional security complexes is, of course, that it makes a big difference whether the structure of the international political economy runs in line with, or against, the structure of the security order. But if the international political economy regionalizes as well, then the two patterns can reinforce each other, tending both to raise the overall importance of the regional level, and to insulate regions from each other. $^{336}$

I believe that this statement very well applies to the integration project that the Southern Cone countries are currently undergoing and brings us back to a key issue. In order to attenuate future commercial disputes, it may greatly benefit the MERCOSUR to implement a supranational body. This should improve the bloc's bargaining capacity in

\footnotetext{
${ }^{333}$ Ibid. p. 17.

${ }^{334}$ Puchala, 1974: 179-180.

${ }^{335}$ Barry Buzan, 1995: 143.

${ }^{336}$ Ibid. p. 144.
} 
the global scene. Lastly, in light of the correlation between economic and security issues, I contend that with the further institutionalization of MERCOSUR, the progress toward democratization and economic competitiveness will be consolidated, and the negative repercussions of the weakening state may finally be resolved. 


\section{REFERENCE}

ABC Color. Paraguay. Cúpula gobernante sabía que huyó Oviedo. April 15, 1999.

Acharya, A. \& Stubbs, R. The Asia-Pacific Region in the Post-Cold War Era Economic Growth, Political Change and Regional Order. In L. Fawcett \& Y. Sayigh (Eds.), The Third beyond the Cold War: Continuity and Change. Oxford; New York: Oxford University Press. 1999.

Acuña, C. \& Smith, W. The Politics of Arms Production and the Arms Race among the New Democracies of Argentina, Brazil, and Chile. In L. Schoultz, W. Smith \& A. Varas (Eds.), Security, Democracy, and Development in U.S. - Latin American Relations. Miami: North-South Center Press, University of Miami. 1994.

Alagappa, M. Regionalism and security: a conceptual investigation. In A. Mack \& J. Ravenhill (Eds.), Pacific Cooperation: Building Economic and Security Regimes in the Asia-Pacific Region. Boulder, Colo.: Westview Press. 1995.

Agence France Presse. Former Paraguayan president flees to Brazil. March 30, 1999.

Agence France Presse. Former Paraguay general takes refuge in Argentina on political asylum. March 30, 1999.

Agence France Presse. One day after stepping down, Paraguay's Cubas gets asylum in Brazil. March 30, 1999.

Argentine Law \#24.059, Title I, Art. 3. 1988.

Argentine Law \#24.059, Title IV, Art. 23. 1988.

Barreto, R. Institutional Corruption and Paraguayan Economic Development. 1996. Available at www.worldpassage,net/wp/Barreto/Papers/Paper3.htm.

BBC Summary of World Broadcasts. Brazil to propose Mercosur relaunch to new Argentine government, minister says. Original source 'O Estado de São Paulo'. Oct. 10, 1999.

Biersteker, T. J. and Weber, C. The Social Construction of State Sovereignty.

In T.J. Biersteker \& C. Weber (Eds.), State Sovereignty as Social Construct. Cambridge ; New York: Cambridge University Press. 1996.

Bluth, C., Kirchner, E \& Sperling, J. Introduction. In Bluth, C., Kirchner, E \& Sperling, J. (Eds.), The Future of European Security. Aldersot, Hants, England ; Brookfield, Vt.: Dartmouth Publishing Company Ltd. 1995. 
Brazilian Federative Constitution, Art. 4. 1988. (Revised 1994).

Brown, S. Ruling Party Wins Paraguay Elections. Manchester Guardian Weekly. May $17,1998$.

Buzan, B. "New Patterns of Global Security in the Twenty-first Century", International Affairs, vol. 67, no. 3, July 1991.

Buzan, B. The Post-Cold War Asia-Pacific Security Order: Conflict or Cooperation? In A. Mack \& J. Ravenhill (Eds.), Pacific Cooperation: Building Economic and Security Regimes in the Asia-Pacific Region. Boulder, Colo.: Westview Press. 1995.

Calvo, P. Acuerdo con Chile para controlar gastos militares. In Clarín newspaper, Argentina. Feb. 17, 1999.

Camargo, L. (1998). Key Note Presentation at the Mercosur Conference: Convergence or Conflict? Nov. 5, 1998.

Camilleri, J. A. Rethinking Sovereignty in a Shrinking, Fragmented World. In R.B.J. Walker \& S. H. Mendlovitz (Eds.), Contending Sovereignties: Redefining Political Community. Boulder, Colo.: Lynne Rienner Publishers. 1990.

Camilleri, J. A. and Falk, J. The End of Sovereignty? : The Politics of a Shrinking and Fragmenting World. Aldersot, Hants, England ; Brooksfield, Vt.: Edward Edgar Publishing Limited. 1992.

Cardoso, O. El Projecto de Seguridad. In Clarín newspaper, Argentina. July 29, 1997.

Chayes, A. \& Chayes, A. H. Introduction. In A. Chayes \& A. H. Chayes (Eds.), Preventing Conflict in the Post-Communist World: Mobilizing International and Regional Organizations. Washington D.C.: The Brookings Institution. 1996.

Cima, M. Comando Sur: Nueva Doctrina de la Seguridad Nacional. Posicion de la Cancilleria Argentina (Position of the Argentine Ministry of Foreign Affairs). 1998.

Clarín newspaper, Argentina. Conflictos Comunes a Ambos Paises. July 28, 1997.

Clarín newspaper, Argentina. Darán tareas policiales a las FF.AA. uruguayas. July 29, 1997.

Clarín newspaper, Argentina. Sí a las Maniobras Conjuntas. July 29, 1997. 
Clarín newspaper, Argentina. Luz verde a una alianza militar. Aug. 14, 1997.

Clarín newspaper, Argentina. Balza recibió elogios del jefe del Comando Sur de EE.UU. Feb. 18, 1998.

Clarín newspaper, Argentina. Menem confirmó las consultas. March 31, 1999.

Clarín newspaper, Argentina. Paraguay, contra Argentina y Uruguay. May 7, 1999.

Clinton, William J. C-SPAN, 9-9-1999.

Coffey, P. The Historical Background to Integration in Latin America. In P. Coffey (Ed.), Latin America - MERCOSUR. Boston: Kluwer Academic Publishers. 1998.

Coll, A. In J. Suchlicki (Ed.), Journal of InterAmerican Studies and World Affairs, vol. 39, no. 1. Miami: North-South Center Press, University of Miami. 1997.

Comellas, E. La Nación newspaper, Argentina. Un Sobresalto en el sen del Mercosur. 04-24-96.

Defense \& Foreign Affairs' Strategic Policy. Paraguay. Copyright 1996 International Media Corporation. May 1996.

Delors, M. Alastair Buchan Memorial Lecture, March 7, 1991. In M. Welsh, Europe United? The European Union and the Retreat from Federalism. St. Martin's Press, New York. 1996.

Deutsch, K. Between Sovereignty and Integration: Conclusion. In G. Ionescu (Ed.), Between Sovereignty and Integration. New York: John Wiley \& Sons Inc. 1974.

Deutsche Presse-Agentur. Paraguay's president ousted twice in standoff with general. 04-23-96.

Downes, R. Emerging Patterns of Security Cooperation in the Western Hemisphere. In North-South Issues - Security, vol. V, no. 1. Miami: North-South Center, University of Miami. 1996.

Economist. Paraguay. Backward March. The Economist Newspaper Ltd. April 27, 1996.

E1 Pais, Spain. Brasil, EE UU y el Vaticano empujaron a Cubas a dimitir como presidente de Paraguay. March 31, 1999. 
Embassy of Uruguay to the United States (1998).

In http://embassy.org/uruguay/econ/mercosur/merc-003.html.

Facts on File World News Digest. Constitutional Crisis Resolved. May 2, 1996.

Facts on File World News Digest. Cubas Sworn In as President. Oct. 1, 1998.

Falk, R. Evasions of Sovereignty. In R.B.J. Walker \& S. H. Mendlovitz (Eds.), Contending Sovereignties: Redefining Political Community. Boulder, Colo.: Lynne Rienner Publishers. 1990.

Franko, P. The Economics of Security. In E. Gamarra (Ed.) Hemisphere A Magazine of the Americas, vol. 7, no. 2. 1996.

Freedman, L. \& Menon, A Conclusion: Defence, States and Integration. In Howorth, J. \& Menon, A. (Eds.), The European Union and National Defence Policy. London \& New York: Routledge. 1997.

Freedom House. Mission to Paraguay (Freedom House Special Report). Washington D.C.: Freedom House. 1989.

Gamarra, E. \& Kincaid, D. Disorderly Democracy: Redefining Public Security in Latin America. Paper presented at the XIX Annual Conference on the Political Economy of the World System, North-South Center, University of Miami. April 21-22, 1995. Revised, July 1995.

Gazeta Mercantil. International pressure against the coup in Paraguay. Gazeta Mercantil Inc. April 23, 1996.

Gazeta Mercantil. Wasmosy Sends Oviedo to Prison for Slanderous Remarks. Oct. 10, 1997.

Ghali, Boutros Boutros. An Agenda for Peace: Preventative Diplomacy, Peacemaking, and Peace-Keeping, United Nations, 1992.

Goodwin, G. L. The Erosion of External Sovereignty. In G. Ionescu (Ed.), Between Sovereignty and Integration. New York: John Wiley \& Sons Inc. 1974.

Guedes de Costa, T. Post-Cold War Military Relations between the United States and Latin America. In L. Schoultz, W. Smith \& A. Varas (Eds.), Security, Democracy, and Development in U.S. - Latin American Relations. Miami: North-South Center Press, University of Miami. 1994.

Guira, J. MERCOSUR as an Instrument for Development. In NAFTA: Law \& Business Review of the Americas. Kluwer Law International. 1997. 
Harris, S. and Mack. A. Security and Economics in East Asia. In S. Harris \&

A. Mack (Eds.), Asia-Pacific Security: The Economics-Politics Nexus. St. Leonards, N.S.W.: Allen \& Unwin Australia Pty. Ltd. 1997.

Hinsley, F.H. Sovereignty. Cambridge ; New York: Cambridge University Press. 1986.

Howorth, J. France. In Howorth, J. \& Menon, A. (Eds.), The European Union and National Defence Policy. London \& New York: Routledge. 1997.

Ionescu, G. Between Sovereignty and Integration: Introduction. In G. Ionescu (Ed.), Between Sovereignty and Integration. New York: John Wiley \& Sons Inc. 1974.

La Nación newspaper, Argentina. Menem se solidarizó con Wasmosy. April 23, 1996.

La Nación newspaper, Argentina. La Función Policial no es delegable. August 2, 1999.

La Nación. Editorial II: Oviedo y el asilo político. April 8, 1999.

La Nación newspaper, Argentina. Un juez paraguayo pidió la extradición de Lino Oviedo. July 29, 1999.

La Nación newspaper, Argentina. Oviedo no contaría ya con el respaldo argentino. August 4, 1999.

La Nación newspaper, Argentina. González Macchi: un gesto inamistoso. Sept. 4, 1999.

La Nación newspaper, Argentina. Solicitan el juicio político de Di Tella. Sept. 4, 1999.

La Nación newspaper, Argentina. Paraguay llamó a su embajador en la Argentina. Sept. 4, 1999.

La Nación newspaper, Argentina. Paraguay llamó a su embajador en la Argentina. Sept. 4, 1999.

La Nación newspaper, Argentina. Oviedo un alto costo político. Sept. 5, 1999.

La Nación newspaper, Argentina. Sospechas de Saguier sobre denuncias de legisladores. Sept. 10, 1999.

La Nación newspaper, Argentina. Yacyretá sigue bajo la lupa. Sept. 10, 1999.

La Nación newspaper, Argentina. Brasil prefiere quedarse al margen. Sept. 11, 1999. 
La Nación newspaper, Argentina. Toma: Paraguay tiene doble mensaje. Oct. 5, 1999.

La Nación newspaper, Argentina. Descuentan en Brasil la Victoria de De la Rúa. Oct. 10, 1999.

Lambert, P. The Regime of Alfredo Stroessner. In P. Lambert \& A. Nickson (Eds.), The Transition to Democracy in Paraguay. New York: St. Martin's Press. 1997a.

Lambert, P. Assessing the Transition. In P. Lambert \& A. Nickson (Eds.), The Transition to Democracy in Paraguay. New York: St. Martin's Press. $1997 \mathrm{~b}$.

Latin American Weekly Report. Dramatic upheaval forces Cubas out. March 30, 1999.

Latin American Weekly Report. Solution of Paraguayan crisis was first success of Mercosur Democratic Clause. March 30, 1999.

Latin American Weekly Report, 04-13-99.

Linz, J. \& Stepan, A. Problems of Democratic Transitions and Consolidation: Southern Europe, South America, and Post-Communist Europe. Baltimore, The Johns Hopkins University Press. 1996.

Lucángeli, J. Argentina and the Challenge of MERCOSUR. In P. Coffey (Ed.), Latin America-MERCOSUR. Boston: Kluwer Academic Publishers. 1998.

Lynn Doty, R. Sovereignty and the Nation: Constructing the Boundaries of National Identity. In T.J. Biersteker \& C. Weber (Eds.), State Sovereignty as Social Construct. Cambridge; New York: Cambridge University Press. 1996.

Mack, A. \& Ravenhill, J. Economic and Security Regimes in the Asia-Pacific Region. In A. Mack \& J. Ravenhill (Eds.), Pacific Cooperation: Building Economic and Security Regimes in the Asia-Pacific Region. St. Leonards, N.S.W.: Westview Press. 1995.

Manzetti, L. Economic Integration in the Southern Cone. In North-South Focus MERCOSUR. Miami: North-South Center, University of Miami. Dec. 1992.

Mares, D. Inter-American Security Communities: Concepts and Challenges. In L. Schoultz, W. Smith \& A. Varas (Eds.), Security, Democracy, and Development in U.S. - Latin American Relations. Miami: North-South Center Press, University of Miami. 1994.

Marquis, C. In El Nuevo Herald, Miami. June 6, 1997. 
Martini, C. \& Lezcano, C. The Armed Forces. In P. Lambert \& A. Nickson (Eds.), The Transition to Democracy in Paraguay. New York: St. Martin's Press. 1997.

Masi, F. Foreign Policy. In P. Lambert \& A. Nickson (Eds.), The Transition to Democracy in Paraguay. New York: St. Martin's Press. 1997.

Mena, F. Hacia la Reformulación del Concepto de la Seguridad Continental. In Fuerzas Armadas y Sociedad, year 13, no. 3. July-Sept. 1998.

Menon, A. Introduction. In Howorth, J. \& Menon, A. (Eds.), The European Union and National Defence Policy. London \& New York: Routledge. 1997.

Millet, R. The Future of Latin America's Armed Forces. In R. Millet \& M. Gold-Biss (Eds.), Beyond Praetorianism: The Latin American Military in Transition. Miami: North-South Center Press, University of Miami. 1996.

Millet, R. In J. Suchlicki (Ed.), Journal of InterAmerican Studies and World Affairs, vol. 39, no. 1. Miami: North-South Center Press, University of Miami. 1997.

Montero, C. Inter Press Service. Paraguay: Wasmosy Will Stand His Ground. April 14, 1998.

Morelli, A. (Argentine undersecretary for MERCOSUR) Interview with the author. Mar. 20, 1998.

Moss, A. Analisis de la Politica de Seguridad y defensa de los Estados Unidos para America Latina y el Caribe. Miami: North-South Center, University of Miami. 1995.

Morrison, C. E. Interdependence, Policy Networks, and Security in Asia-Pacific. In Harris, S. \& Mack, A. (Eds.), Asia-Pacific Security: The Economics-Politics Nexus. St. Leonards, N.S.W.: Allen \& Unwin Australia Pty. Ltd. 1997.

Mujica, M. EL MERCOSUR. In Pulecio, J. R. \& Franco, A. (Eds.) Sociedad Civil e Integración en las Américas. Bogotá: Pontificia Universidad Javeriana. 1997.

New York Times. Paraguay Uprising costs Soldiers Jobs. Jan. 1, 1997.

New York Times. Paraguay's Ruling Party Names Coup Suspect as Top Candidate. Sept. 9, 1997.

New York Times. Latin America's Armies are down, but not out. June 2, 1999.

New York Times. European Union Vows to Become Military Power. June 4, 1999. 
Nickson, A. Corruption and the Transition. In P. Lambert \& A. Nickson (Eds.), The Transition to Democracy in Paraguay. New York: St. Martin's Press. 1997a.

Nickson, A. The Wasmosy Government. In P. Lambert \& A. Nickson (Eds.), The Transition to Democracy in Paraguay. New York: St. Martin's Press. $1997 \mathrm{~b}$.

Norse, Edward L. "The Transformation of Foreign Policies." In World Politics 22, no. 3. 1970.

Notisur - Latin American Political Affairs. Paraguay: Threat of a Coup by Defiant General Averted. Latin American Institute, University of Mexico. May 3, 1996.

Notisur - Latin American Political Affairs. President Juan Carlos Wasmosy engulfed in a new dispute with dissident General. Latin American Institute, University of Mexico. Feb. 7, 1997.

NotiSur - Latin American Political Affairs. Paraguay: President Juan Carlos Wasmosy Engulfed in a New Dispute with Dissident General. Feb. 07, 1997.

Nye, J. International Regionalism. Boston: Little, Brown and Company. 1968.

O'Keefe, T. An Assessment of MERCOSUR's Present Legal Framework and Institutions and How They Affect MERCOSUR's Chances For Success. In Westlaw, Copyright by the New York State Bar Association. 1993.

Osava, M., Ronzoni, R. \& González, G. Argentina: President-elect welcomed by MERCOSUR partners. In Inter Press Service. Oct. 26, 1999.

Perelli, C. \& Rial, J. Changing Military World Views: The Armed Forces of South America in the 1990s. In R. Millet \& M. Gold-Biss (Eds.), Beyond Praetorianism: The Latin American Military in Transition. Miami: North-South Center Press, University of Miami. 1996.

Powers, N. The Transition to Democracy in Paraguay: Problems and Prospects. A Rapporteur's Report. Working Paper \# 171. The Helen Kelogg Institute for International Studies. Indiana: Notre Dame University. Jan. 1992.

Puchala, D. J. Internal Order and Peace: An Integrated Europe in World Affairs. In G. Ionescu (Ed.), Between Sovereignty and Integration. John Wiley \& Sons Inc. 1974.

Puchala, D. J. and Fagan, S. I. "International Politics in the 1970s: The Search for a Perspective.” International Organization, vol. 28, no. 2, Spring 1974. 
Riquelme, M. \& Riquelme, J. Political Parties. In P. Lambert \& A. Nickson (Eds.), The Transition to Democracy in Paraguay. New York: St. Martin's Press. 1997.

Rojas Aravena, F. America Latina: Alternativas y Mecanismos de Prevencion en Situaciones Vinculadas a la Soberania Territorial. In Paz y Seguridad en las Americas magazine, no. 14. FLACSO-Chile. Oct. 1997.

Rojas Aravena, F. Globalización y Orden Internacional. In F. Rojas Aravena (Ed.), Globalización, America Latina y la Diplomacia de Cumbres. FLACSO-Chile. 1998.

Rojas Aravena, F. Security Regimes in the Western Hemisphere: A View from Latin America. In L. Schoultz, W. Smith \& A. Varas (Eds.), Security, Democracy, and Development in U.S. - Latin American Relations. Miami: North-South Center Press, University of Miami. 1994.

Rotella, S. The Los Angeles Times. Ex-General in Paraguay Makes Run for Presidency - From Jail. Jan. 24, 1998.

Rummel, R. The European Union's Politics - Diplomatic Contribution to the Prevention of Ethno-National Conflict. In A. Chayes \& A. H. Chayes (Eds.), Preventing Conflict in the Post-Communist World: Mobilizing International and Regional Organizations. Washington, D. C.: The Brookings Institution. 1996.

Schoultz, L. U.S. Values and Approaches to Hemispheric Security Issues. In L. Schoultz, W. Smith \& A. Varas (Eds.), Security, Democracy, and Development in U.S. - Latin American Relations. Miami: North-South Center Press, University of Miami. 1994.

Seidelmann, R. Towards a Common European Security Policy. In Bluth, C., Kirchner, E \& Sperling, J. (Eds.), The Future of European Security. Aldersot, Hants, England; Brookfield, Vt.:Dartmouth Publishing Company Ltd. 1995.

Sen, G. Developing States and the End of the Cold War: Liberalization,

Globalization, and their Consequences. In L. Fawcett \& Y. Sayigh (Eds.), The Third beyond the Cold War: Continuity and Change. Oxford ; New York: Oxford University Press. 1999.

Sheetz, T. A Peace Dividend in South America? : Defense Conversion in Argentina and Chile. In N. O. Gleditsch, O. Bjerkholt, A. Cappelen, R. P. Smith \& J. P. Dunne (Eds.), The Peace Dividend. Amsterdam ; New York: Elsevier. 1996.

Southern Cone Report. Menem applies for Nato link. August 3, 1999. 
Spiro, H.J. Interdependence: A Third Option between Sovereignty and Supranational Integration. In G. Ionescu (Ed.), Between Sovereignty and Integration. New York: John Wiley \& Sons Inc. 1974.

Stark, J. Rethinking Security in the Americas. In North-South Issues - Democratization. Miami: North-South Center, University of Miami. 1992.

Stubrin, M. Los valores en juego. In La Nación newspaper. Sept. 10, 1999.

Taylor O'Neal, C. Dispute Resolution as a Catalyst for Economic Integration and for Deepening Integration: NAFTA and MERCOSUR? In Northwestern Journal of International Law and Business. Northwestern University. 1997.

Telám News Agency. August 10, 1998.

Telám News Agency. Argentine minister says Oviedo asylum decision was to protect Mercosur. March 30, 1999.

Tererè News. Paraguay. Como Ocurrio el Brutal Atentado. March 30, 1999.

Tererè News. Paraguay. Cardoso Tuvo un Papel Esencial para la Renuncia de Cubas. March 30, 1999.

Tererè News. Paraguay. Vicepresidente pide un gesto a Oviedo: "Que se vaya". March 30, 1999.

Tererè News. Paraguay. Diputados explican su rechaso a concesión de asilo a Segovia. May 3, 1999.

Tererè News. Paraguay. Cancilleres de Uruguay y Paraguay inician el proceso para normalizar las relaciones. May 9, 1999.

Thakur, R. From National to Human Security. In Harris, S. \& Mack, A. (Eds.), Asia-Pacific Security: The Economics-Politics Nexus. St. Leonards, N.S.W.: Allen \& Unwin Australia Pty. Ltd. 1997.

The Associated Press. Former General's Candidacy Ends as Court Upholds Prison Sentence. April 17, 1998.

Torres, C. Importante paso hacia la supranacionalidad en el Mercosur. Editorial Continental, March 3, 1998.

Torres, C. Oviedo Accuses Wasmosy of fostering coup attempt. Inter Press Service. June 6, 1996. 
Tulchin, J. In J. Suchlicki (Ed.), Journal of InterAmerican Studies and World Affairs, vol. 39, no. 1. Miami: North-South Center Press, University of Miami. 1997.

U.S. Department of Defense, Office of International Affairs. United States Security Strategy for the Americas. September, 1995.

Valenzuela, A. Paraguay: The Coup that Didn't Happen. In Journal of Democracy, vol. 8, no. 1. Jan. 1997.

Varas, A. Post-Cold War Security Interests and Perceptions of Threat in the Western Hemisphere. In L. Schoultz, W. Smith \& A. Varas (Eds.), Security, Democracy, and Development in U.S. - Latin American Relations. Miami: North-South Center Press, University of Miami. 1994.

Welsh, M. Europe United? The European Union and the Retreat from Federalism. New York: St. Martin's Press. 1996.

Xinhua News Agency. OAS Permanent Council meets on Paraguay.. 04-23-96.

Xinhua News Agency. Brazil evaluates crisis in Paraguay. 04-23-96 